\title{
Análise do código de conduta das instituições financeiras da BM\&FBovespa à luz das recomendações do instituto brasileiro de governança corporativa
}

The code of conduct analysis of financial companies listed on the BM\&FBovespa based on recommendations issued by the Brazilian institute of corporate governance

Análisis del código de conducta de las instituciones financieras de la BM\&FBovespa a la luz de las recomendaciones del instituto brasileño de gobierno corporativo

\section{Aline Oliveira Araújo}

Bacharel em Ciências Contábeis pela Universidade Federal do Rio Grande do Sul

Endereço: Av. João Pessoa, n॰ 52, Bairro Campus Centro

CEP: 90040-000 - Porto Alegre/RS - Brasil

E-mail: alinearaujo55@gmail.com

Telefone: (51) 3308.3502

\section{Ariel Behr}

Doutor em Administração pela Universidade Federal do Rio Grande do Sul

Professor na Universidade Federal do Rio Grande do Sul

Endereço: Av. João Pessoa, n॰ 52, Bairro Campus Centro

CEP: 90040-000 - Porto Alegre/RS - Brasil

E-mail: ariel.behr@ufrgs.br

Telefone: (51) 3308.3502

\section{Fernanda da Silva Momo}

Mestre em Administração pela Universidade Federal do Rio Grande do Sul

Endereço: Av. João Pessoa, n॰ 52, Bairro Campus Centro

CEP: 90040-000 - Porto Alegre/RS - Brasil

E-mail: fernandamomo@yahoo.com.br

Telefone: (51) 3308.3502

Artigo recebido em 21/08/2016. Revisado por pares em 26/06/2017. Reformulado em 26/10/2017. Recomendado para publicação em 08/03/2018 por Carlos Eduardo Facin Lavarda (Editor-Chefe). Publicado em 28/03/2018. 


\title{
Resumo
}

O código de conduta e ética das organizações é um instrumento que objetiva estruturar políticas e normas claras em relação ao comprometimento com os diferentes stakeholders. Nesse contexto, o objetivo desta pesquisa é analisar a estrutura e conteúdo dos temas dos códigos de conduta das empresas do setor de atuação financeiro listadas na BM\&FBovespa à luz das recomendações feitas pelo Instituto Brasileiro Governança Corporativa (IBGC). Quanto aos procedimentos metodológicos, esta pesquisa é classificada como quantitativa e qualitativa, descritiva e documental. No mês de abril de 2016, coletou-se os códigos de conduta divulgados pelos 20 bancos listados no setor de atuação financeiro da BM\&FBovespa em seus websites. Os resultados demonstram que, em relação à aderência dos códigos, os bancos têm um índice médio de $62 \%$ de adesão às recomendações feitas pelo IBGC. Assim, confirmou-se a hipótese da pesquisa de que houve aumento da aderência dos códigos ao longo dos últimos anos.

Palavras-chave: Código de conduta; Código de ética; Governança corporativa

\begin{abstract}
The organizations' code of conduct and ethics is an instrument with the purpose of structuring internal policies and clear rules in regards to the commitment with all stakeholders. In this context, the objective of this research is to analyze the structure and content of the themes of the codes of conduct for financial companies listed on the Brazilian stock market, the BM\&FBovespa, based on recommendations issued by the IBGC. Regarding the methodological procedures, the research is classified as qualitative and quantitative, descriptive and documentary. In April of 2016, the codes of conduct published by the main 20 listed banks of the BM\&FBovespa were gathered from their websites. Obtained results demonstrate the adherence to the codes. Banks that were the subject of this study have an average adherence rate of $62 \%$ in regards to the recommendations made by the $I B G C$. Data analysis confirms the hypothesis of an adhesion increase over the last years.
\end{abstract}

Keywords: Code of conduct; Code of ethics; Corporate governance

\section{Resumen}

El código de conducta y ética de las organizaciones es un instrumento que tiene como objetivo estructurar las políticas y normas claras en relación con el compromiso con los diferentes actores. En este contexto, el objetivo de esta investigación es analizar la estructura y contenido de los temas de los códigos de conducta de las empresas del sector de actuación financiero listados en la BM\&FBovespa a la luz de las recomendaciones formuladas por el Instituto Brasileño de Gobierno Corporativo (IBGC). En cuanto a los procedimientos metodológicos, esta investigación se clasifica como cualitativa y cuantitativa, descriptiva y documental. En abril de 2016, recogido los códigos de conducta publicados por los 20 bancos que figuran en el sector financiero de la BM\&FBovespa en sus sitios web. Los resultados muestran que, en relación con el cumplimiento de los códigos, los bancos tienen una tasa promedio de $62 \%$ de adherencia a las recomendaciones formuladas por el IBGC. Por lo tanto, la hipótesis de la investigación se confirmó que hubo un aumento de la adhesión de códigos durante los últimos años.

Palabras clave: Código de conducta; Código de ética; Gobierno corporativo

\section{Introdução}

Em tempos nos quais a atual legislação de combate à corrupção se encontra em voga, um instrumento que pode ganhar maior importância e ser tido como aliado positivo das organizações é o código de conduta e ética. Esse tem como objetivo estruturar políticas e regras 
Análise do código de conduta das instituições financeiras da BM\&FBovespa à luz das recomendações do instituto brasileiro de governança corporativa

claras a respeito do comprometimento com os diferentes stakeholders, tanto internos como externos à organização. Assim, apresenta-se, segundo o Instituto Brasileiro de Ética nos Negócios (2014), como "um registro que configura ou pressupõe relações de seriedade e responsabilidade, condições para bons negócios".

Antes da promulgação da Lei Anticorrupção, Lei n ${ }^{0}$ 12.846/2013, os atos de corrupção ocorridos numa empresa resultavam sanções isoladas, enquanto as entidades poderiam não ser penalizadas. O que muda após a promulgação da lei em janeiro de 2014 é que a mesma prevê punição das empresas envolvidas em atos de corrupção (BRASIL, 2013). Além disso, essa lei, em seu art. $7^{\circ}$, parágrafo $8^{\circ}$, prevê "a existência de mecanismos e procedimentos internos de integridade, auditoria e incentivo à denúncia de irregularidades e a aplicação efetiva de códigos de ética e de conduta no âmbito da pessoa jurídica" (BRASIL, 2013, p. 3).

Nesse sentido, pode-se visualizar a existência de instrumentos como o código de conduta como uma forma de limitar a ação dos gestores, algo destacado como relevante para as organizações conforme Simons (1994) e de teorias como a da agência (EISENHARDT, 1989). Entretanto, cabe destacar que esses mecanismos não estão restritos ao que está prescrito em lei conforme exemplificou-se anteriormente. Portanto, identifica-se a importância desses mecanismos como forma de fomentar relações organizacionais que sejam fundamentadas na reciprocidade e justiça (BRIDOUX; STOELHORST, 2014).

Assim, de acordo com Andrade e Rosseti (2009) mudanças no cenário de negócios do ponto de vista externo, como o surgimento de mercados globalizados, contribuíram para levar a governança corporativa a uma posição de grande relevância dentre as práticas mais modernas de alta gestão. No Brasil, o Instituto Brasileiro de Governança Corporativa (IBGC), principal referência nacional para o desenvolvimento das melhores práticas sobre esse tema, define que o código de conduta deve ser criado pela diretoria conforme os princípios e políticas determinados pelo Conselho de Administração e por esse aprovado. Além disso, também deve determinar responsabilidades ambientais e sociais e ter claro e expresso os princípios nos quais está fundamentado, além de refletir de maneira adequada a cultura da empresa (IBGC, 2009).

Tendo em vista a relevância da Governança Corporativa e sua abrangência que perpassa a legislação objetivando influenciar os agentes da sociedade no sentido de mais transparência, justiça e responsabilidade, opta-se nesse estudo por enfocar as instituições financeiras. Essas instituições possuem grande impacto na sociedade e maior regulação por meio do BACEN (Banco Central do Brasil), uma das principais autoridades monetárias do país.

Nesse setor, espera-se, naturalmente, que os códigos de conduta das instituições sejam completos o suficiente para contemplar os elementos de Governança Corporativa. Entretanto, como constatado por Azevedo (2010) em seu estudo, é possível afirmar apenas de forma parcial que os setores regulados possuem maior grau de adesão ao IBGC quando comparados com setores não regulados. Além disso, esse autor identificou que segmentos diferenciados de governança da BM\&FBovespa não apresentam necessariamente um maior grau de adesão às práticas recomendadas pelo IBGC quando comparadas com menor nível de exigência (AZEVEDO, 2010).

Nesse sentido, torna-se relevante entender não apenas em que grau as organizações financeiras listadas na BM\&FBovespa aderem ao IBCG, mas de que forma abordam os assuntos recomendados pelo IBGC em mecanismos como os códigos de conduta das organizações. Portanto, levando em conta a relação entre as questões éticas e de conduta nas organizações e as boas práticas de governança corporativa, esta pesquisa visa atender à seguinte questão: Como as instituições financeiras listadas na BM\&FBovespa abordam os assuntos recomendados pelo IBGC a constarem nos códigos de conduta das organizações? Desta forma o objetivo do estudo 
é analisar a estrutura e conteúdo dos temas dos códigos de conduta das empresas do setor de atuação financeiro listadas na BM\&FBovespa à luz das recomendações feitas pelo IBGC.

A partir desta pesquisa há o interesse em identificar a estrutura temática dos códigos e verificar se houve evolução em relação à pesquisa de Azevedo (2010) no que se refere a adesão às recomendações do IBGC sobre o código de conduta por parte das instituições financeiras listadas na BM\&FBovespa. Além de conhecer a forma como as empresas abordam as recomendações do IBGC em seus códigos de conduta, e como estes assuntos são tratados. A partir desse conhecimento, a criação de um código de ética pode ser subsidiada nesta pesquisa.

O estudo está organizado, além desta introdução, destinada à contextualização do tema e introdução da questão problema que motiva a pesquisa, em uma base teórica envolvendo Ética Empresarial e Código de Conduta, Governança Corporativa e o IBGC, Diretrizes de Conduta, além de outros estudos relacionados. $\mathrm{Na}$ terceira seção, são relatados os procedimentos metodológicos utilizados e, na seção quatro, são descritos e analisados os dados obtidos. Por fim, na quinta seção, são apresentadas as considerações finais acerca do que foi estudado e sugeridas abordagens para estudos futuros.

\section{Referencial Teórico}

Inicialmente descreve-se a ética empresarial e o código de conduta, conceituando os principais termos como ética, código de conduta, etc. E em seguida define-se governança corporativa, o Instituto Brasileiro de Governança Corporativa e suas diretrizes de conduta do código das melhores práticas de governança corporativa do IBGC.

\section{1 Ética Empresarial e Código de Conduta}

O termo ética, segundo Srour (2014, p.29), "origina-se do grego ethos, que vem a ser o caráter distintivo, os costumes, hábitos e valores de uma determinada coletividade ou pessoa". De acordo com Arruda, Whitaker e Ramos (2009, p.82), "A ética é a parte da filosofia que estuda a moralidade dos atos humanos, enquanto livres e ordenados ao seu fim último". Para o Instituto Brasileiro de Ética nos Negócios (2014, p.21), "Todas as noções que se tem de ética, normativas ou não, baseiam-se em uma teoria que sustenta a racionalidade, a liberdade e a responsabilidade das pessoas, individualmente e entre si".

Em um recorte histórico, destaca-se que, segundo Stevens (2008, p.601), "após Watergate e a renúncia do presidente Nixon em 1974, escândalos corporativos e atos de comportamentos inapropriados proliferaram nos Estados Unidos e continuaram por várias décadas", comprometendo os padrões éticos das organizações. Para melhorar sua imagem, as empresas recorreram aos códigos de ética, por meio dos quais procuravam tornar públicas suas virtudes e criar uma impressão melhor dos investidores (AZEVEDO 2010).

Assim, é possível vislumbrar o esse instrumento como uma forma de conseguir estabelecer um relacionamento baseado na confiança, tratamento justo com os stakeholders. Destaca-se que existência desse tipo de relacionamento entre organização e stakeholders leva a um conhecimento maior sobre a função e utilidade desses atores de forma a permitir a obtenção de vantagens e maior geração de valor para os stakeholders ao passo que a organização entende como esses desejam ser tratados (SARTURI, 2016; FREEMAN; HARRISON; WICKS, 2007).

Nesse sentido, o Código de Ética pode ser definido, conforme o Instituto Brasileiro de Ética nos Negócios (2014, p.21) como:

a declaração do conjunto de direitos, deveres e responsabilidades empresariais para com os Stakeholders, refletindo a cultura, os princípios e os valores, a atuação 
Análise do código de conduta das instituições financeiras da BM\&FBovespa à luz das recomendações do instituto brasileiro de governança corporativa

socioambiental e o conjunto das normas de conduta para dirigentes, executivos e colaboradores bem como para as empresas integrantes da cadeia produtivas, mediante os quais atuam as premissas que enriquecem os processos decisórios da empresa e orientam o seu comportamento. Além disto, deve ser o principal instrumento da Governança Corporativa e da gestão estratégica para se tornar um aliado das empresas no caminho que levará ao Desenvolvimento Sustentável.

Segundo Arruda, Whitaker e Ramos (2009), o código de ética concretiza e deixa formalizada a expectativa da organização quanto à conduta esperada por parte de seus executivos e funcionários. O seu alicerce está nos princípios e filosofia da empresa, amparado em sua missão e valores. Aqui, enfatiza-se que o conhecimento por parte da organização de quem são os seus stakeholders permitirá um melhor alinhamento de expectativas nesse relacionamento. Nesse sentido, tem-se que, conforme a teoria dos stakeholders, há uma relação positiva entre a justiça em relação aos stakeholders e o desempenho organizacional. Entretanto, cabe ressaltar que não todos os stakeholders estarão preocupados com questões de justiça organizacional conforme argumentam Bridoux e Stoelhorst (2014), de forma a ser ainda mais relevante o conhecimento de quem são esses stakeholders e quais seus interesses para uma gestão das ações empresariais tendo em vista esses interesses.

Existem diversas vantagens - e desvantagens também - em adotar o código de ética na organização. Para Arruda, Whitaker e Ramos (2009), dentre as vantagens, as principais são: Prover critérios ou diretrizes para que as pessoas conheçam formas éticas de se conduzir; garantir tratamento igualitário na forma de encaminhamento de questões específicas; estimular comprometimento por parte de todos os colaboradores; assegurar interesses públicos e de profissionais que colaboram para a organização; e agregar valor à imagem da empresa.

Dentre as desvantagens, as principais são: haver inconsistências e incoerências entre o que está presente no código de conduta e o que se vive na organização. Além disso, implantar um código de ética encomendado e engavetado, que não seja vivido na prática pelas pessoas (ARRUDA; WHITAKER; RAMOS, 2009). Assim, compreendendo algumas questões relativas a ética empresarial e o código de conduta das organizações, apresenta-se na próxima subseção conceitos relativos a governança corporativa (GC) e o Instituto Brasileiro de GC (IBGC).

\subsection{Governança Corporativa na Visão do IBGC}

O Instituto Brasileiro de Governança Corporativa "é uma organização exclusivamente dedicada à promoção da Governança Corporativa no Brasil e o principal fomentador das práticas e discussões sobre o tema no país, tendo alcançado reconhecimento nacional e internacional" (IBGC, 2009. p.4). A presença do IBGC como fomentador das boas práticas de governança é nítida no momento atual corporativo do país (AZEVEDO 2010).

Segundo o IBGC $(2009$, p.19) a governança corporativa é "o sistema pelo qual as organizações são dirigidas, monitoradas e incentivadas, envolvendo os relacionamentos entre proprietários, conselho de administração, diretoria e órgãos de controle". Ainda, as boas práticas de governança transformam princípios em indicações objetivas, alinhando interesses com a finalidade de resguardar e otimizar o valor da organização, facilitando seu acesso a recursos e colaborando para sua longevidade.

$\mathrm{Na}$ apresentação de seu Código de Melhores Práticas de Governança Corporativa, o Instituto Brasileiro de Governança Corporativa (2009) afirma que mudanças no ambiente organizacional brasileiro, como o renascimento do mercado de capitais, reforçaram a necessidade da implantação de mecanismos de controle pela Governança Corporativa. Nesse sentido, destacam-se alguns capítulos abordados no Código do IBGC como Propriedade, 
Conselho de Administração, Gestão, Auditoria Independente, Conselho Fiscal e Conduta e Conflito de Interesses (IBGC, 2009).

Segundo o Instituto Brasileiro de Governança Corporativa (2009), cada capítulo trata das práticas e recomendações para cada um dos órgãos citados anteriormente, pertencentes ao sistema de governança das organizações. Ainda, traz o último capítulo que "trata de padrões de conduta e comportamento, aplicáveis a um ou mais agentes, além de propor políticas e práticas para evitar conflitos de interesses e mau uso dos ativos e informações relativas à organização" (IBGC, 2009, p.15). Aqui cabe ressaltar a Teoria da Agência, ao passo que o gestor é autointeressado o código de conduta pode ser vislumbrado como uma forma de limitar atuação desse gestor.

\subsection{Diretrizes de Conduta}

O IBGC (2009) determina no Código das Melhores Práticas de Governança Corporativa que o código de conduta deve compreender a relação entre conselheiros, diretores, sócios, colaboradores, e demais partes interessadas (stakeholders). Também afirma que conselheiros e executivos não devem praticar sua autoridade em benefício próprio ou de terceiros. Sendo assim, o código "deve refletir adequadamente a cultura da empresa e enunciar, com total clareza, os princípios em que está fundamentado. Deve ainda apresentar caminhos para denúncias ou resolução de dilemas de ordem ética" (IBGC, 2009, p.66). Esse conceito reforça, a relevância desse mecanismo como um mediador dos conflitos de interesses existentes nas organizações conforme prediz a Teoria da Agência.

A seguir, apresenta-se a definição sobre cada um dos temas relacionados pelo IBGC que devem constar no código de conduta de uma organização, à luz de alguns autores e normas.

Quadro 1 - Assuntos do Código de Conduta e suas definições

\begin{tabular}{|c|c|c|}
\hline Assunto & Definição & Fonte \\
\hline $\begin{array}{l}\text { Cumprimento das } \\
\text { leis e pagamento } \\
\text { de tributos }\end{array}$ & $\begin{array}{l}\text { "Espera-se de uma organização que aplica as boas práticas de } \\
\text { governança corporativa o estrito cumprimento das leis e o } \\
\text { pagamento de seus tributos, contribuindo para o desenvolvimento } \\
\text { da sociedade e do seu país". }\end{array}$ & $\begin{array}{c}\text { AZEVEDO, } 2010 \\
\text { p. } 64\end{array}$ \\
\hline $\begin{array}{l}\text { Operações com } \\
\text { partes } \\
\text { relacionadas }\end{array}$ & $\begin{array}{l}\text { Compete aos membros do Conselho de Administração o dever de } \\
\text { monitorar e gerir potenciais conflitos de interesses dos sócios, dos } \\
\text { executivos da entidade e dos membros do Conselho de modo a } \\
\text { prevenir abusos em transações entre partes relacionadas. "O } \\
\text { conselheiro deve zelar para que essas transações sejam conduzidas } \\
\text { dentro de parâmetros de mercado, em termos de prazos, taxas e } \\
\text { garantias, e que estejam claramente refletidas nos relatórios da } \\
\text { organização". }\end{array}$ & IBGC, 2009, p.68 \\
\hline $\begin{array}{l}\text { Uso de ativos da } \\
\text { organização }\end{array}$ & $\begin{array}{l}\text { "Os ativos, tangíveis e intangíveis fazem parte do patrimônio da } \\
\text { organização e se destinam a auxiliar na realização dos objetivos } \\
\text { dessa. Assim, o uso desses bens deve se restringir ao estrito interesse } \\
\text { do serviço. Com esse escopo, os regulamentos internos da } \\
\text { organização devem contemplar orientações especificas sobre o uso, } \\
\text { as responsabilidades e as exceções admitidas". }\end{array}$ & $\begin{array}{c}\text { AZEVEDO, } 2010 \\
\text { p. } 64\end{array}$ \\
\hline $\begin{array}{l}\text { Conflito de } \\
\text { interesses }\end{array}$ & $\begin{array}{l}\text { "Há conflito de interesses quando alguém não é independente em } \\
\text { relação à matéria em discussão e pode influenciar ou tomar decisões } \\
\text { motivadas por interesses distintos daqueles da organização". }\end{array}$ & IBGC, 2009, p.67 \\
\hline
\end{tabular}


Análise do código de conduta das instituições financeiras da BM\&FBovespa à luz das recomendações do instituto brasileiro de governança corporativa

\begin{tabular}{|c|c|c|}
\hline $\begin{array}{l}\text { Informações } \\
\text { privilegiadas }\end{array}$ & $\begin{array}{l}\text { Segundo o Manual das Políticas de Divulgação e de Negociação de } \\
\text { Valores Mobiliários, informação privilegiada é "relativa a Atos ou } \\
\text { Fatos relevantes até que sejam divulgados aos órgãos reguladores, } \\
\text { às Bolsas de Valores e outras entidades similares e, } \\
\text { simultaneamente, aos acionistas e investidores em geral". "O } \\
\text { Código deve enquadrar como violação ao princípio básico da } \\
\text { equidade o uso de informações privilegiadas para benefício próprio } \\
\text { ou de terceiros. A organização deve também dispor, em documento } \\
\text { específico, sobre os procedimentos a serem observados para evitar } \\
\text { ou punir o uso indevido dessas informações". }\end{array}$ & $\begin{array}{l}\text { BM\&FBOVESPA, } \\
2015, \text { p.3 } \\
\text { IBGC, 2009, p.68 }\end{array}$ \\
\hline $\begin{array}{l}\text { Política de } \\
\text { negociação das } \\
\text { ações da empresa }\end{array}$ & $\begin{array}{l}\text { "A companhia aberta deve adotar, por deliberação do seu Conselho } \\
\text { de Administração, uma política de negociação de valores } \\
\text { mobiliários de sua emissão". "Assim, o código deve detalhar todas } \\
\text { as condições aplicáveis às negociações de seus ativos mobiliários de } \\
\text { modo a propiciar total transparência e ampla abrangência da } \\
\text { respectiva informação". }\end{array}$ & $\begin{array}{l}\text { IBGC, } 2009 \text { p.69 } \\
\text { AZEVEDO, 2010, } \\
\text { p.66 }\end{array}$ \\
\hline $\begin{array}{l}\text { Processos } \\
\text { judiciais e } \\
\text { arbitragem }\end{array}$ & $\begin{array}{l}\text { É recomendado que caso conflitos entre sócios e administradores e } \\
\text { entre estes e a entidade não tenham uma negociação bem-sucedida, } \\
\text { haja resolução, preferencialmente, por meio de mediação e, na } \\
\text { ausência de acordo, por arbitragem. }\end{array}$ & IBGC, 2009 \\
\hline Whistle-blower & $\begin{array}{l}\text { "Pessoa que informa as instâncias competentes sobre atividades } \\
\text { ilegais ou desvios de conduta por parte de pessoas relacionadas com } \\
\text { a organização e que tenham potencial de afetar a organização. As } \\
\text { denúncias podem ser efetuadas às pessoas competentes dentro da } \\
\text { organização ou aos reguladores, imprensa ou entidades públicas". }\end{array}$ & IBGC, 2009, p.66 \\
\hline $\begin{array}{l}\text { Prevenção e } \\
\text { tratamento de } \\
\text { fraudes }\end{array}$ & $\begin{array}{l}\text { "A organização deve estabelecer uma política com conceitos e as } \\
\text { diretrizes para a prevenção e o combate a atos ilícitos". }\end{array}$ & IBGC, 2009, p.70 \\
\hline $\begin{array}{l}\text { Pagamentos ou } \\
\text { recebimentos } \\
\text { questionáveis }\end{array}$ & $\begin{array}{l}\text { Deve-se haver uma colocação formal sobre qual comportamento } \\
\text { espera-se em relação a pagamentos e recebimentos anormais aos } \\
\text { negócios. Essa política evita decisões pessoais e possíveis } \\
\text { comprometimentos à imagem da organização. }\end{array}$ & AZEVEDO,2010 \\
\hline $\begin{array}{l}\text { Recebimento de } \\
\text { presentes e } \\
\text { favorecimentos }\end{array}$ & $\begin{array}{l}\text { "A orientação geral deve ser a de que tanto a empresa quanto seus } \\
\text { funcionários recusem o recebimento de presentes e outros } \\
\text { favorecimentos passíveis de questionamento do ponto de vista } \\
\text { moral. Outras situações que possam configurar favorecimento } \\
\text { pessoal, como, por exemplo, o custeio de refeições e viagens } \\
\text { precisam ser detalhadamente reguladas no código de conduta da } \\
\text { organização de forma a não deixar margens para interpretações } \\
\text { dúbias". }\end{array}$ & $\begin{array}{l}\text { AZEVEDO, } 2010 \\
\text { p. } 68\end{array}$ \\
\hline Doações & $\begin{array}{l}\text { "A fim de assegurar maior transparência sobre a utilização dos } \\
\text { recursos dos seus sócios, as organizações devem elabora uma } \\
\text { política sobre suas contribuições voluntárias, inclusive políticas. } \\
\text { Anualmente, a organização deve divulgar, de forma transparente, } \\
\text { todos os custos oriundos de suas atividades voluntárias". }\end{array}$ & IBGC, 2009, p.69 \\
\hline $\begin{array}{l}\text { Atividades } \\
\text { políticas }\end{array}$ & $\begin{array}{l}\text { "Algumas organizações costumam efetuar contribuições políticas a } \\
\text { partidos e candidatos. Permitem ainda que, em época de campanha } \\
\text { eleitoral, candidatos possam comparecer a suas plantas para } \\
\text { apresentação de planos e solicitação de votos dos funcionários. Cabe } \\
\text { ao Conselho de Administração traçar as diretrizes de como serão } \\
\text { conduzidas as doações e contribuições, observada a legislação } \\
\text { pertinente, e de como deve se portar o público interno em relação às } \\
\text { atividades políticas no ambiente de trabalho". }\end{array}$ & $\begin{array}{l}\text { AZEVEDO, } 2010 \\
\text { p. } 69\end{array}$ \\
\hline $\begin{array}{l}\text { Direito à } \\
\text { privacidade }\end{array}$ & $\begin{array}{l}\text { Segundo a CF/88 "São invioláveis, a vida privada, a honra e a } \\
\text { imagem das pessoas". "O código de conduta deve informar, } \\
\text { objetivamente, qual é a política da empresa em relação ao }\end{array}$ & $\begin{array}{l}\text { BRASIL, } 1988 . \\
\text { AZEVEDO, } 2010 \\
\text { p. } 69\end{array}$ \\
\hline
\end{tabular}




\begin{tabular}{|c|c|c|}
\hline & $\begin{array}{l}\text { tratamento de dados pessoais, as responsabilidades que assume } \\
\text { perante as pessoas da organização assim como qual o tratamento a } \\
\text { ser dado em casos de inobservância das regras internas". }\end{array}$ & \\
\hline Nepotismo & $\begin{array}{l}\text { "Nepotismo é o favorecimento dos vínculos de parentesco nas } \\
\text { relações de trabalho ou emprego. As práticas } \\
\text { de nepotismo substituem a avaliação de mérito para o exercício da } \\
\text { função pela valorização de laços de parentesco". }\end{array}$ & $\begin{array}{l}\text { CONSELHO } \\
\text { NACIONAL DE } \\
\text { JUSTIÇA, } 2015 \text {. }\end{array}$ \\
\hline Meio ambiente & $\begin{array}{l}\text { Segundo a ISSO 14001:2015 "um sistema de gestão ambiental } \\
\text { auxilia as organizações a identificar, monitorar, gerenciar e } \\
\text { controlar suas questões de uma forma holística. Ela requer que uma } \\
\text { organização considere questões ambientais relevantes às suas } \\
\text { operações, tais como a poluição do ar, questões de água e esgoto, } \\
\text { gestão de resíduos contaminação do solo, atenuação das alterações } \\
\text { climáticas e adaptação e utilização de recursos e eficiência". }\end{array}$ & ISO, 2015. \\
\hline $\begin{array}{l}\text { Discriminação no } \\
\text { ambiente de } \\
\text { trabalho }\end{array}$ & $\begin{array}{l}\text { Segundo o Art. } 5^{\circ} \text { da Constituição "Todos são iguais perante a lei, } \\
\text { sem distinção de qualquer natureza [...]". "Em consonância com as } \\
\text { determinações legais e com os princípios éticos e de governança } \\
\text { corporativa (respeito às demais partes interessadas), os códigos } \\
\text { devem conter o posicionamento da organização e o tratamento a ser } \\
\text { dispensado para os casos em que se configurem a discriminação no } \\
\text { emprego". }\end{array}$ & $\begin{array}{l}\text { BRASIL, } 1988 . \\
\text { AZEVEDO, } 2010 \\
\quad \text { p. } 71\end{array}$ \\
\hline $\begin{array}{l}\text { Assédio moral ou } \\
\text { sexual }\end{array}$ & $\begin{array}{l}\text { Assédio Sexual "É a abordagem, não consentida, com intenção } \\
\text { sexual ou a insistência inoportuna de alguém que se encontre em } \\
\text { situação privilegiada na hierarquia, formalizada ou não, e que se } \\
\text { utiliza dessa ascendência com vistas a obter favores sexuais de } \\
\text { subalternos ou dependentes. Assédio sexual é crime tipificado no } \\
\text { art. } 216-A \text {, do Código Penal Brasileiro, com redação dada pela Lei } \\
\text { n'10.224, de } 15 \text { de maio de 1991". "Assédio moral é toda e qualquer } \\
\text { conduta abusiva (gesto, palavra, comportamento, atitude, etc.) que, } \\
\text { intencional e frequentemente, atinja a dignidade ou fira a } \\
\text { integridade física ou psíquica de uma pessoa, ameaçando o emprego } \\
\text { ou degradando o ambiente de trabalho". }\end{array}$ & $\begin{array}{l}\text { MANUAL } \\
\text { EMPREGADOR } \\
\text { URBANO, } 2006 \\
\text { p.30 }\end{array}$ \\
\hline $\begin{array}{l}\text { Segurança no } \\
\text { trabalho }\end{array}$ & $\begin{array}{l}\text { De acordo com a Consolidação das Leis do Trabalho (CLT) em seu } \\
\text { artigo 154: "Cabe às empresas: I - cumprir e fazer cumprir as normas } \\
\text { de segurança e medicina do trabalho [...]". }\end{array}$ & BRASIL, 1977 \\
\hline $\begin{array}{l}\text { Exploração de } \\
\text { trabalho adulto ou } \\
\text { infantil }\end{array}$ & $\begin{array}{l}\text { Segundo a CLT nos artigos } 402 \text { e seguintes. "Art. } 402 \text {. Considera- } \\
\text { se menor para os efeitos desta Consolidação o trabalhador de } \\
\text { quatorze até dezoito anos". "Art. 403. É proibido qualquer trabalho } \\
\text { a menores de dezesseis anos de idade, salvo na condição de } \\
\text { aprendiz, a partir dos quatorze anos". }\end{array}$ & BRASIL, 1943 \\
\hline $\begin{array}{l}\text { Relações com a } \\
\text { comunidade }\end{array}$ & $\begin{array}{l}\text { "A inserção do tema comunidade no código de conduta da } \\
\text { organização, além de servir como um orientador para ações quer } \\
\text { sejam institucionais, quer sejam pessoais (seus membros) em } \\
\text { relação à comunidade do entorno, serve para demonstrar para o } \\
\text { mercado como um todo e para aquela comunidade, em específico, a } \\
\text { importância e o valor que ela representa para a organização". }\end{array}$ & $\begin{array}{c}\text { AZEVEDO, } 2010 \\
\text { p. } 74\end{array}$ \\
\hline $\begin{array}{l}\text { Uso de álcool e } \\
\text { drogas }\end{array}$ & $\begin{array}{l}\text { Segundo a CLT, em seu artigo } 482 \text {, configura justa causa para } \\
\text { rompimento do contrato de trabalho, dentre outros motivos, a } \\
\text { embriaguez habitual ou em serviço. }\end{array}$ & BRASIL, 1943 \\
\hline
\end{tabular}

Fonte: Elaborado pelos autores (2016)

Assim, após a apresentação das diretrizes de conduta, na próxima subseção, serão apresentados os estudos relacionados as temáticas abordadas nessa pesquisa. 
Análise do código de conduta das instituições financeiras da BM\&FBovespa à luz das recomendações do instituto brasileiro de governança corporativa

\subsection{Estudos Relacionados}

Ao analisarem 600 códigos de ética de empresas europeias e contrastarem esses códigos com empresas americanas similares, Langlois e Schlegelmilch (1990) identificaram que as empresas europeias adotavam menos esse mecanismo do que as empresas americanas. Além disso, havia indícios que os códigos se encaminharam para a Europa através de subsidiárias de empresas americanas. Entretanto os autores destacaram a existência de diferenças no conteúdo dos códigos desses dois locais tendo em vista a abordagem dada a ética em cada localidade (LANGLOIS; SCHLEGELMILCH, 1990).

A relação entre os códigos de ética e comportamento foi realizada no estudo de Schwartz (2001). Para isso, o autor realizou 57 entrevistas com funcionários, gerentes e diretores de ética de quatro empresas canadenses. Como resultado, o autor identificou que os códigos de ética influenciam potencialmente o comportamento dos agentes corporativos (SCHWARTZ, 2001).

Estudos de códigos de ética corporativos desde 2000 foram revisados por Stevens (2008) que concluiu que os mesmos podem ser instrumentos eficazes para moldar o comportamento ético e orientar a tomada de decisão dos funcionários. Ele defende que a cultura e a comunicação eficaz são fatores essenciais para um código de sucesso. Além disso, afirma que se os códigos forem incorporados na cultura e abraçados por seus líderes estarão suscetíveis ao êxito.

As principais abordagens usadas nos códigos de conduta de uma amostra de doze empresas internacionalizadas foram analisadas por Silva e Gomes (2008) que, também, verificaram o uso do mesmo como instrumento de controle gerencial. Identificaram que apenas duas das doze entidades analisadas atenderam ou exibiram maior proximidade às premissas descritas pelos principais autores e normas discutidos no estudo.

Whitaker e Ramos (2010) analisaram o relacionamento entre a Ética e as melhores práticas de Governança Corporativa e, também, os princípios e valores éticos, bem como as linhas mestras das melhores práticas da Governança Corporativa adotadas pelo IBGC. Ambos defendem que uma empresa não deve se envolver com a Governança Corporativa apenas para atrair investimentos e ser bem-sucedida, mas também estar preocupada com adoção de critérios éticos para atingir seu fim (WHITAKER; RAMOS, 2010).

Uma investigação do grau de adesão às recomendações do IBGC pelas empresas listadas na BM\&FBovespa na preparação de seus códigos de ética empresarial foi realizada por Azevedo (2010). Através dos websites, coletou 166 códigos disponíveis e aplicou testes estatísticos para apurar a associação entre o grau de adesão ao código do IBGC e o segmento de listagem das empresas e a associação entre o grau de adesão ao código do IBGC e seu setor de atuação. Ao final do estudo identificou-se que segmentos diferenciados de governança da BM\&FBovespa não apresentam necessariamente um maior grau de adesão às práticas recomendadas pelo IBGC quando comparadas com menor nível de exigência. Além disso, confirmou-se apenas de forma parcial que os setores regulados possuem maior grau de adesão ao IBGC quando comparados com setores não regulados (AZEVEDO, 2010).

Erwin (2011) estudou a importância do conteúdo do código de conduta na determinação da eficácia desse código, examinando a relação entre a qualidade do código de conduta e o desempenho ético. Como resultado, esse autor identificou que as organizações que possuem códigos de conduta de alta qualidade foram significativamente mais representadas entre os principais sistemas de classificação em relação a temas como cidadania corporativa, sustentabilidade, comportamento ético e percepção pública. Nesse sentido, os resultados sugerem que "a qualidade do código pode desempenhar um papel crucial na eficácia dos 
códigos de conduta e sua capacidade de transformar culturas organizacionais" (ERWIN, 2011, p. 535).

Baseado em uma pesquisa das maiores corporações do Canadá, Singh (2011, p. 385), buscou "avaliar empiricamente os determinantes da eficácia dos códigos de ética corporativos, regredindo as percepções dos gerentes sobre a eficácia do código contra diversos elementos dos programas de ética". Como resultados, o autor identificou, a partir de uma modelo estatístico significativo, cinco variáveis independentes explicam $43,8 \%$ da variação na efetividade percebida dos códigos corporativos de ética, sendo essas variáveis: propósito do código; implementação do código; código interno de comunicação/execução; comunicação externa do código e utilidade do código (SINGH, 2011).

O código de ética foi estudado por Davidson e Stevens (2013) como um mecanismo efetivo da governança corporativa de forma a estudar a eficácia de um código de ética em uma configuração experimental. Nesse estudo, os autores tiveram como resultado que um código de ética só melhora o comportamento do gerente e a confiança do investidor quando o código incorpora uma escolha de certificação pública pelo gerente, caso não haja essa certificação pública o comportamento do gerente não melhora e a confiança dos investidores se deteria se deteriora ao longo do tempo (DAVIDSON; STEVENS, 2013).

\section{Procedimentos Metodológicos}

A pesquisa realizada pode ser classificada quanto a três aspectos: quanto à abordagem do problema; quanto aos seus objetivos; e quanto aos procedimentos técnicos utilizados. No que tange à abordagem do problema, esta pesquisa se classifica em quantitativa e qualitativa, pois traduz em números o nível de adesão às recomendações do IBGC pelas empresas listadas na BM\&FBovespa e busca conhecer na essência a forma como as mesmas abordam esses assuntos recomendados em seus códigos de conduta. Segundo Raupp e Beuren (2013, p. 92), "a abordagem quantitativa caracteriza-se pelo emprego de instrumentos estatísticos, tanto na coleta quanto no tratamento dos dados". Segundo Oliveira $(2011$, p.82) "as pesquisas que possuem abordagem qualitativa podem apresentar a complexidade de certo problema, avaliar como suas variáveis interagem entre si e com o todo".

De acordo com seus objetivos, a pesquisa é caracterizada como descritiva, pois tem o intuito de descrever a forma como as empresas listadas na BM\&FBovespa abordam os assuntos recomendados pelo IBGC em seus respectivos códigos de conduta. Gil (2008, p. 28) afirma que "as pesquisas deste tipo têm como objetivo primordial a descrição das características de determinada população ou fenômeno ou estabelecimento de relações entre variáveis".

Com base nos procedimentos técnicos utilizados, o estudo pode ser classificado como pesquisa documental. Gil (2008, p. 157) define esse tipo de pesquisa como aquela em que "a fonte de coleta de dados está restrita a documentos, escritos ou não, constituindo o que se denomina de fontes primárias". Para realização do estudo, foram utilizados os códigos de conduta disponibilizados pelas empresas em seus websites, caracterizados, portanto, como fontes primárias.

A população definida na pesquisa são as 28 empresas listadas na BM\&FBovespa, no setor de atuação Financeiro, subsetor Intermediários Financeiros, segmento Bancos em 30/09/2015. A amostra utilizada corresponde às empresas, dentro da população da pesquisa, que divulgavam em seus websites seus códigos de conduta/ética (posição em setembro de 2015). Sendo assim, fazem parte da amostra 20 empresas. 
O trabalho de coleta foi realizado em duas etapas, sendo a coleta dos códigos de condutas disponibilizados nos websites, e a conferência dos dados de coleta. Também foram armazenados todos os códigos pesquisados, além de uma pesquisa realizada em abril de 2016 para conferir se houve atualização nos mesmos, transcorridos sete meses da primeira coleta. Constatou-se que cinco empresas revisaram e apresentaram novos códigos em seus websites, sendo os mesmos substituídos na coleta.

Ainda, revisou-se nesta segunda coleta a lista de empresas. Foi constatado na lista de Bancos da BM\&FBovespa que não constava uma empresa presente na amostra, tendo sido verificado ainda em abril de 2016 que a mesma foi vendida, sendo assim suas operações foram incorporadas por outra instituição financeira. O banco foi substituído na amostra por outra instituição que divulgava seu código de conduta em website em abril de 2016.

Os dados coletados foram classificados com base nos 22 assuntos recomendados pelo IBGC, presentes no quadro 1 (seção 2.3). Foi realizada a leitura dos 20 códigos para identificar as menções aos assuntos recomendados pelo IBGC (existência ou não) no item 6.1.1 da $4^{\mathrm{a}}$ edição do Código de Melhores Práticas de Governança Corporativa. Todos os assuntos presentes nos 20 códigos foram transcritos em planilha de Excel e categorizados por assunto recomendado pelo IBGC.

Para análise dos dados, foi utilizada a análise documental, que segundo Teixeira (2003, p.194) "a maioria das técnicas de análise (...) tem o propósito de contar a frequência de um fenômeno e procurar identificar relações entre os fenômenos, com a interpretação dos dados recorrendo a modelos conceituais definidos a priori". Portanto, foi feita análise de essência dos códigos, buscando além de encontrar a menção ou não dos assuntos em seu texto, a forma de abordagem da empresa referente aos mesmos e como são tratados dentro da organização, como valores, princípios, condutas mandatórias ou inaceitáveis.

No que tange a análise da estrutura de apresentação de todos os documentos, foi realizada uma tabulação em Excel da estrutura de cada um dos códigos analisados de forma a permitir identificar diferenças ou padrões na forma como os bancos compõem seus códigos de conduta e ética. Ainda, avaliou-se essência dos códigos em que se optou intencionalmente, devido a uma restrição de espaço, por apresentar na análise dos dados (subseção 4.3) os tópicos que mais se destacaram dentre os bancos em cada item analisado. Para essa última análise, utilizou-se como base categórica dos tópicos os assuntos recomendados pelo IBGC a constarem no código de conduta. Assim, os dados foram novamente tabulados em planilha Excel em que cada linha da planilha correspondia a um tópico do IBGC e cada coluna uma empresa permitindo assim uma análise da essência dos códigos em relação a cada item recomendado pelo IBGC. Além disso, para essa análise utilizou-se o software Nvivo11 para tratamento e codificação dos dados, bem como para a produção de nuvens de frequência de palavras. As nuvens criadas restringem-se somente aos assuntos recomendados pelo IBGC a constarem no código de conduta que estavam presentes em mais de 50\% dos códigos analisados. Além disso, as nuvens visam apresentar ao leitor um panorama dos termos mais utilizados pelos códigos de conduta para representar os assuntos recomendados pelo IBGC.

\section{Análise dos Dados}

Para cumprir o objetivo proposto, serão apresentados neste capítulo os resultados alcançados através da análise dos dados coletados. O mesmo foi segredado em três seções, sendo a primeira destinada à análise de aderência dos códigos, a segunda referente à estrutura 
na qual os códigos são apresentados, e por fim, na terceira seção, será analisada a essência dos assuntos presentes nos mesmos.

\subsection{Análise de aderência dos Códigos}

O objetivo desta ação é apresentar uma visão geral do nível de aderência das empresas aos assuntos recomendados a constarem no código de conduta, pelo IBGC. Para isso, foi elaborada a Tabela 1, na qual foram relacionados os temas e suas menções (existência ou não), nos respectivos códigos.

Tabela 1 - Assuntos constantes nos códigos das vinte instituições financeiras da BM\&FBovespa

\begin{tabular}{l} 
Leis e Tributos \\
\hline Parts. Relacion
\end{tabular}

A partir da Tabela 1 é possível observar que a menção total dos assuntos presentes nos códigos dos bancos varia entre $32 \%$ e $91 \%$, sendo o Itaú Unibanco o destaque e o BANPARA o banco com menor adesão. Quando comparados com a adesão dos códigos estudados por Azevedo (2010), os quais foram coletados em julho de 2010, os resultados apresentados na podem ser considerados satisfatórios, dado o aumento na adesão geral aos assuntos recomendados pelo IBGC.

Todos os bancos revisaram e atualizaram seus códigos de conduta, tendo acrescido uma média de cinco assuntos por código, além de quatro bancos, incluindo o BANPARA, BTG Pactual, Itaú SA e Mercantil do Brasil, terem divulgado os mesmos em seus websites, fato que não ocorria em 2010. Isso demonstra maior transparência por parte dos bancos e, principalmente, comprometimento e atenção com as questões éticas pertinentes à organização.

Além disso, cabe ressaltar que a revisão dos códigos de conduta representa, de alguma forma, que as organizações estão atentas para que esses códigos representem de forma mais verossimilhante suas expectativas em relação aos seus executivos e funcionários (WHITAKER; 
Análise do código de conduta das instituições financeiras da BM\&FBovespa à luz das recomendações do instituto brasileiro de governança corporativa

RAMOS, 2009). Esse alinhamento entre código (em que consta a expectativa da organização) e prática é importante para um melhor alinhamento de expectativas nesse relacionamento e diminuindo possíveis conflitos como o da agência, sendo necessário para isso o conhecimento de quem são esses stakeholders e quais seus interesses para uma gestão das ações empresariais tendo em vista esses interesses (BRIDOUX; STOELHORST, 2014).

Ainda em relação a esse fato constatado, destaca-se que mesmo que os códigos de ética se apresentam como potenciais instrumentos para moldar o comportamento e tomada de decisão dos atores organizacionais, isso só será possível quando esse foram incorporados na cultura da organização (SCHWARTZ, 2001; STEVENS 2008). Portanto, a revisão desses códigos representa até certo grau a validação desses códigos pelos gerentes, conforme defendido por Davidson e Stevens (2013). Isso ocorre, pois, a certificação pública do gerente é possível quando os códigos são constantemente revistos para representares exatamente as expectativas da organização tendo em vista o olhar dos executores.

Em relação a adesão dos códigos, em uma comparação à pesquisa realizada por Azevedo (2010), bancos como Amazônia, Sofisa e Itaú Unibanco aumentaram sua adesão em mais de $100 \%$ na menção dos assuntos recomendados pelo IBGC. Já outros cinco bancos - Banco do Brasil, Banestes, BRB, Indusval e Mercantil do Brasil - atualizaram seus códigos de conduta entre setembro de 2015, quando foi realizada a coleta dos dados e abril de 2016, quando os mesmos foram revisados. Houve uma média de aumento na adesão dos mesmos em $92 \%$.

$\mathrm{Na}$ tabela 2 foram relacionados os resultados e seus respectivos percentuais das respostas positivas referentes aos 22 assuntos recomendados pelo IBGC.

Tabela 2 - Quantidades e percentuais de adesões aos assuntos recomendados pelo IBGC (2009)

\begin{tabular}{c|l|c|c|c|}
\hline \multicolumn{1}{|c|}{ Assuntos recomendados pelo IBGC } & Sim & $\%$ & Não \\
\hline 1 & Cumprimento das leis e pagamentos de tributos & 20 & $100 \%$ & 0 \\
\hline 2 & Operações com partes relacionadas & 2 & $10 \%$ & 18 \\
\hline 3 & Uso de ativos da organização & 16 & $80 \%$ & 4 \\
\hline 4 & Conflito de interesses & 18 & $90 \%$ & 2 \\
\hline 5 & Informações privilegiadas & 13 & $65 \%$ & 7 \\
\hline 6 & Política de negociação das ações da empresa & 7 & $35 \%$ & 13 \\
\hline 7 & Processos judiciais e arbitragem & 0 & $0 \%$ & 20 \\
\hline 8 & Whistle-blower & 16 & $80 \%$ & 4 \\
\hline 9 & Prevenção e tratamento de fraudes & 20 & $100 \%$ & 0 \\
\hline 10 & Pagamentos ou recebimentos questionáveis & 12 & $60 \%$ & 8 \\
\hline 11 & Recebimento de presentes e favorecimentos & 15 & $75 \%$ & 5 \\
\hline 12 & Doações & 4 & $20 \%$ & 16 \\
\hline 13 & Atividades políticas & 12 & $60 \%$ & 8 \\
\hline 14 & Direito à privacidade & 10 & $50 \%$ & 10 \\
\hline 15 & Nepotismo & 10 & $50 \%$ & 10 \\
\hline 16 & Meio ambiente & 16 & $80 \%$ & 16 \\
\hline 17 & Discriminação no ambiente de trabalho & 20 & $100 \%$ & 0 \\
\hline 18 & Assédio moral ou sexual & 18 & $90 \%$ & 2 \\
\hline 19 & Segurança no trabalho & 9 & $65 \%$ & 7 \\
\hline 20 & Exploração de trabalho adulto ou infantil & $45 \%$ & 11 \\
\hline 21 & Relações com a comunidade & 73 & $62 \%$ & 167 \\
\hline 22 & Uso de álcool e drogas & $75 \%$ & 5 \\
\hline & & $75 \%$ & 13 \\
\hline
\end{tabular}

Fonte: Elaborado pelos autores (2016). 
Com base na Tabela 2 é possível perceber que temas como Leis e Tributos, assim como Discriminação no ambiente de trabalho são abordados por todos os códigos de conduta, visto que são assuntos regulamentados por legislação tributária e trabalhista. Por outro lado, o assunto Processos Judiciais e Arbitragem não foi citado por nenhum código enquanto o tema Operações com Partes Relacionadas foi minimamente abordado dentro da amostra, sendo tratado por apenas dois bancos. Uma possível justificativa para a ocorrência é o fato de tratarem-se de assuntos que envolvem a alta administração das entidades, e que podem ser tratados em outras políticas e regulamentos internos da companhia.

O índice médio geral de adesão aos assuntos recomendados é de $62 \%$, relativamente baixo dado a importância das questões éticas dentro das organizações de um setor como este que é regulado. Por outro lado, se comparado ao desempenho dos códigos estudados por Azevedo (2010), o índice geral apresentado na Tabela 1 pode ser considerado satisfatório haja vista que em 2010 , esse índice era de apenas $40 \%$. Fato que demonstra a crescente importância que vem sendo dada ao código de conduta.

Assuntos como Operações com partes relacionadas, Whistle-blower e Doações que não eram abordados na base anterior passaram a ser tratados nos novos códigos. Ainda, assuntos como Política de Negociação de Ações, Prevenção e tratamento de fraudes e Uso de álcool e drogas que eram pontualmente citados, tiveram uma média de seis vezes mais menções nos novos códigos de conduta.

\subsection{Análise de Estrutura dos Códigos}

Nesta seção serão apresentados os principais tópicos que compõe a forma como as empresas apresentam seus códigos de conduta. Na Tabela 3 estão relacionados os tópicos presentes nas estruturas e a presença ou não dos mesmos em cada código das vinte empresas analisadas.

Tabela 3 - Quantidades de tópicos abordados na estrutura dos códigos de conduta

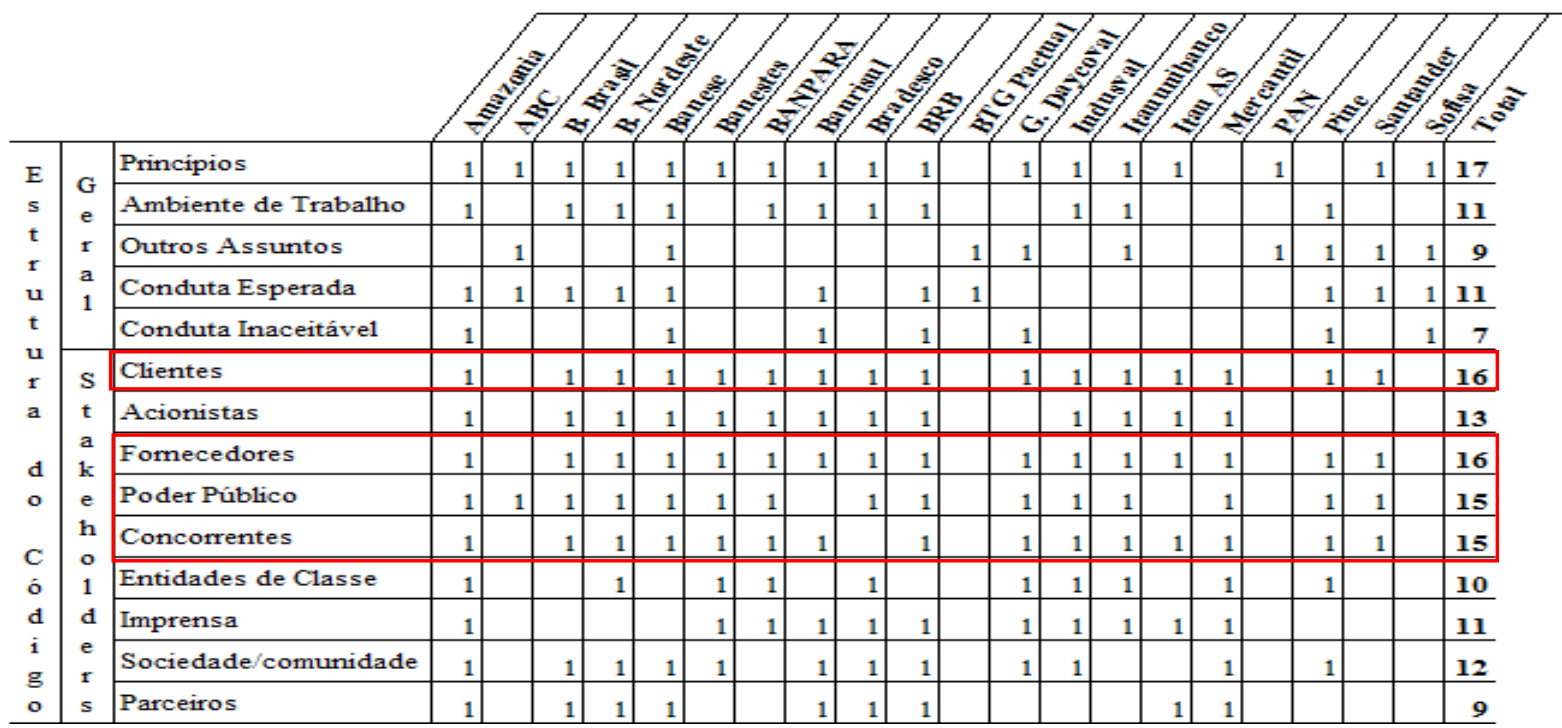

Fonte: Elaborada pelos autores (2016).

Legenda: Consta $=1$; não consta $=$ vazio. 
A partir da Tabela 3 é possível observar que pouco mais da metade dos bancos, em geral, seguem uma mesma forma na estruturação de seus códigos. Tópicos como Princípios e Valores da organização, Relacionamento com Clientes, com Fornecedores, com Poder Público e com Concorrentes estão presentes em mais de $80 \%$ dos códigos o que demonstra um certo padrão no arcabouço dos mesmos.

Além disso, os principais grupos de relações internas e externa de uma organização (stakeholders), são abordados por, em média, mais da metade dos bancos analisados. Em seu tópico de abrangência o Instituto Brasileiro de Governança Corporativa $(2009$, p.66) afirma que "o código de conduta deve abranger o relacionamento entre conselheiros, diretores, sócios, funcionários, fornecedores e demais partes interessadas (stakeholders)".

Nesse sentido, foi possível identificar que os tópicos mais abordados em relação aos stakeholders foram: Clientes, Fornecedores, Poder Público e Concorrentes. Nesse sentido, destaca-se que essas são, naturalmente as partes mais interessadas em relação as atividades desse setor. Em relação ao Poder Público, esse aparece nos códigos como um dos stakeholders mais abordados por se tratar de um setor regulamentado.

Também tópicos como Conduta Esperada pela organização, assim como condutas consideradas inaceitáveis são temas de estrutura, o que corrobora que segundo Arruda, Whitaker e Ramos (2009), o código concretiza e deixa formalizada a expectativa da organização quanto à conduta esperada por parte de seus executivos e funcionários. O seu alicerce está nos princípios e filosofia da empresa, amparado em sua missão e valores.

Além disso, a similaridade dos tópicos abordados tem relação com o fato dessas organizações pertencerem ao mesmo setor econômico destacando assim similaridades referente ao ambiente organizacional ao qual estão expostas. Ou seja, da mesma forma com que Langlois e Schlegelmilch (1990) destacaram a existência de diferenças no conteúdo dos códigos de locais diferentes tendo em vista a abordagem dada a ética em cada localidade, pode-se transpor esse resultado de forma que a localidade represente também o setor econômico estudado. Assim, empresas do mesmo setor econômico tendem a ter padrões similares na estrutura de seus códigos de ética, ainda mais quando esse setor é regulamentado.

\subsection{Análise da Essência dos Códigos}

Nesta seção busca-se apresentar como os bancos tratam, na essência, os assuntos recomendados pelo IBGC a constarem no código de conduta, em consonância com as normas e legislação vigentes.

\section{1) Cumprimento das leis e pagamento de tributos}

Este assunto foi abordado por todos os bancos presentes nessa amostra, o que mostra a importância do cumprimento da legislação vigente como um todo. $\mathrm{O}$ banco BRB trata o assunto como mandatória: "Todo o corpo funcional deverá: Cumprir a legislação vigente no país, bem como as políticas e normas internas do Banco na realização de suas atividades".

O banco Itaú SA aborda o tema como compromisso do banco: "Cidadania corporativa: Cumprimos de forma exemplar as leis, normas e regulamentos dos países em que operamos em todas as instâncias do direito: administrativo, ambiental, cível, comercial, trabalhista, tributário etc.", o que demonstra compromisso dos bancos em geral, atendendo " o estrito cumprimento das leis e o pagamento de seus tributos, contribuindo para o desenvolvimento da sociedade e do seu país" (AZEVEDO 2010, p.64). 
Ressalta-se que a presença desse tópico em todos os códigos pode ser justificada também pela alta regulação desse setor. A nuvem das 30 palavras mais frequentes nos códigos de todas as empresas analisadas reforça a ligação desse tópico do código com normas, leis, atividades, legislação e regulamentos.

Figura 1 - Nuvem de palavras do tópico Cumprimento das leis e pagamento de tributos

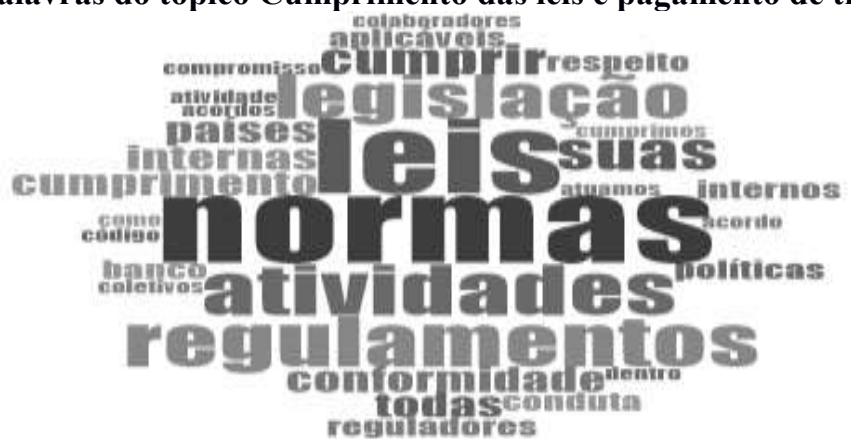

Fonte: Elaborada pelos autores (2016).

2) Operações com partes relacionadas

Temática tratada por apenas dois bancos, o que representa apenas $10 \%$ da amostra estudada. O Itaú Unibanco determina como conduta esperada "Ater-se às regras preestabelecidas, aprovadas em assembleia e previamente informadas ao mercado, para realizar negócios ou operações com as partes relacionadas, para que se mantenham a equidade e o cumprimento das políticas e procedimentos do Itaú Unibanco", a fim de obter-se maior transparência e preservar o princípio da independência.

Já o Itaú SA Investimentos trata o assunto com um rol de condutas com os públicos de relacionamentos, dentre elas: "Nenhuma operação ou negócio com as partes relacionadas é realizado visando atender interesses pessoais de acionistas, administradores ou de terceiros". Ambas as abordagens em convergência com o que o IBGC recomenda, que devem ser monitorados e geridos conflitos de interesses de modo a prevenir abusos em transações entre partes relacionadas (IBGC, 2009).

Aqui ressalta-se a relevância desse tópico na mediação de interesses entre as partes que se relacionam com as instituições financeiras. Mesmo assim, a aderência dessas organizações a esse tópico no código de ética é pequena. Nesse sentido, destaca-se que uma atenção maior a esse assunto poderia impactar em um melhor relacionamento com os stakeholders, ampliando ainda mais a qualidade dos códigos, tornando-os mais eficazes, conforme destacado por Erwin (2011).

3) Uso dos ativos da organização

Assunto abordado pela maioria dos bancos, compreendendo $80 \%$ da amostra. Em geral, como sendo uma conduta proibitiva o uso de ativos para fins pessoais. $\mathrm{O}$ banco Amazônia trata das condutas inaceitáveis: "utilizar o patrimônio e instalações do banco ou de seus recursos humanos para fins particulares e/ou escusos". Já o banco Mercantil aborda em seu capítulo de responsabilidades: "É nosso dever utilizar corretamente, manter e proteger o patrimônio físico (instalações, equipamentos, materiais, etc.) e o patrimônio abstrato (pesquisas, processos, patentes, marcas, etc.) do banco.

Em forma de recomendação ou mandatória, todos os bancos definem norma de uso desses bens, pois "os regulamentos internos da organização devem contemplar orientações 
especificas sobre a utilização, as responsabilidades e as exceções admitidas. Assim, o uso desses bens deve se restringir ao estrito interesse do serviço" (AZEVEDO 2010, p.64).

Nesse tópico, ressalta-se que as organizações, ao deixarem explícito as normativas em relação ao uso dos ativos da organização, demonstram não estarem se envolvendo com a Governança apenas para atrair investimentos, mas também se preocupa com adoção de critérios éticos para atingir seu objetivo como organização (WHITAKER; RAMOS, 2010). Assim, essa atenção dada pelas instituições financeiras a esse tópico pode ser contatada também nas palavras mais frequentes utilizadas nesse tópico que remetem a diversos ativos $\mathrm{e}$ comportamentos em relação a esses ativos das organizações.

Figura 2 - Nuvem de palavras do tópico uso dos ativos da organização

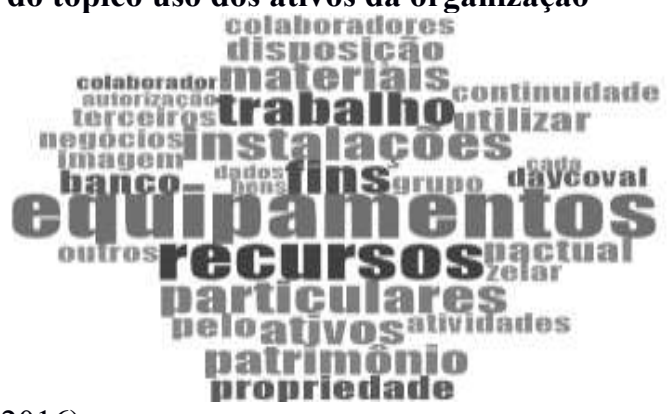

Fonte: Elaborada pelos autores (2016).

\section{4) Conflito de interesses}

Este tema é tratado por quase toda a amostra, representando $90 \%$ da mesma. O Santander trata em capítulo específico, como regra geral, que "Os Sujeitos ao Código deverão atuar sempre de forma que seus interesses particulares, os de seus familiares ou de outras pessoas a eles vinculadas não prevaleçam sobre os interesses do banco ou de seus clientes".

Já o Pine dispõe que: "Todos os profissionais no exercício de suas funções devem estar atentos à ocorrência de situações de conflito de interesses, comunicando em caso afirmativo seu superior, à área de Compliance ou o Comitê de Ética". Essas regras estão em linhas com o que o IBGC discorre que "quando alguém não é independente em relação à matéria em discussão [...], essa pessoa deve manifestar, tempestivamente, seu conflito de interesses. Caso não o faça, outra pessoa poderá manifestar o conflito" (IBGC, 2009, p.67).

Além disso, a existência desse tópico vai ao encontro da mediação de possíveis conflitos como os descritos pela Teoria da Agência. Nesse sentido, o código nesse tópico pode ser visto como um limitador da ação do gestor. A seguir, a Figura 3 apresenta as palavras mais frequentes utilizadas pelas organizações nesse tópico, reforçando assim as análises anteriores.

Figura 3 - Nuvem de palavras do tópico conflito de interesses

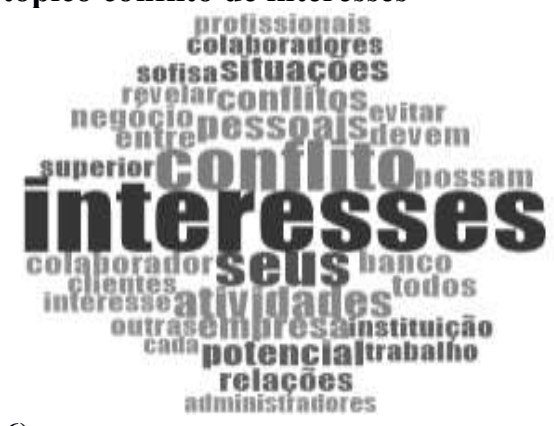

Fonte: Elaborada pelos autores (2016). 
5) Informações privilegiadas

Assunto tratado por pouco mais da metade dos códigos, resultando em $65 \%$ da amostra total. O BTG Pactual, dispõe que: "Identificamos, compreendemos e protegemos a confidencialidade das "informações materiais não públicas", ou seja, informações confidenciais que, se divulgadas, provavelmente afetariam o preço de ativos financeiros".

O PAN determina que "É considerado crime negociar ou divulgar informações relevantes ainda não disponibilizadas ao mercado (i) para proveito próprio ou de terceiros; e (ii) cuja divulgação provavelmente influenciaria nas decisões de investimento e o preço dos títulos e valores mobiliários". Em seu código, o IBGC esclarece que "o Código de Conduta deve enquadrar como violação [...] o uso de informações privilegiadas para benefício próprio ou de terceiros" (IBGC, 2009, p.68). A Figura 4 a seguir apresenta as palavras mais frequentes nos códigos das organizações.

Figura 4 - Nuvem de palavras do tópico informações privilegiadas

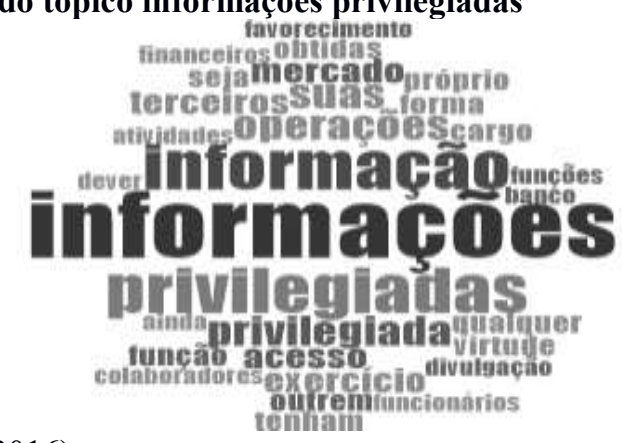

Fonte: Elaborada pelos autores (2016).

6) Política de negociação das ações da empresa

Tema abordado por pouco mais de um terço da amostra deste estudo. $\mathrm{O}$ banco Bradesco dispõe: "Os administradores, funcionários e/ou colaboradores, devem cumprir rigorosamente as políticas de divulgação de ato ou fato relevante e de negociação de valores mobiliários de emissão do Banco Bradesco S.A., aprovadas pelo Conselho de Administração do Banco". O banco Pine determina que se deve "Aderir e cumprir a Política de Investimentos Pessoais do PINE, observando as regras vigentes sobre a negociação de ações no mercado, respeitando os períodos de vedação".

O banco PAN orienta que "Todos devem tomar conhecimento e aderir às Políticas de Divulgação de Ato ou Fato Relevante e de Negociação de Valores Mobiliários do banco". Essas regras estão em consonância com a recomendação do IBGC que "A companhia aberta deve adotar, por deliberação do seu Conselho de Administração, uma política de negociação de valores mobiliários de sua emissão" (IBGC, 2009, p.69). Sendo, portanto, um tópico relevante para propiciar "total transparência e abrangência da respectiva informação" (AZEVEDO 2010, p.66).

Processos judiciais e arbitragem

Único assunto presente nas recomendações que não foi abordado por nenhum dos vinte bancos. O IBGC dispõe que "Caso não seja possível uma negociação bem-sucedida entre as partes, os conflitos entre sócios e administradores e entre estes e a organização devem ser resolvidos, preferencialmente, por meio de mediação e, se não houver acordo, arbitragem" (IBGC, 2009, p.27). Ainda, o Instituto Brasileiro de Governança Corporativa (2009) recomenda 
a inserção destes mecanismos no Estatuto ou contrato social da empresa, motivo pelo qual, por exemplo, esse tema pode não ter sido tratado nos respectivos códigos.

\section{8) Whistle-blower}

Tema tratado por quase todos os códigos estudados, representando $80 \%$ do total da amostra. O banco Santander orienta que "Todo funcionário que tiver conhecimento da prática de um ato supostamente ilícito ou de um ato de descumprimento deste Código ou de políticas internas vigentes, deverá comunicar o fato diretamente ao Compliance". Já o bando do Brasil determina que "É dever do funcionário: reportar eventual desvio ético ou irregularidade a um dos administradores ou à Ouvidoria Interna".

O IBGC define Whistle-blower como "Pessoa que informa as instâncias competentes sobre atividades ilegais e/ou imorais ou desvios de conduta por parte de pessoas relacionadas com a organização e que tenham potencial de afetá-la". Recomenda ainda que o código deve "apresentar caminhos para denúncias ou resolução de dilemas de ordem ética" (IBGC, 2009, p.66). Destaca-se que alguns códigos apresentam de forma mais explícita dos caminhos para a realização das denúncias. Essa declaração explícita auxilia na efetividade percebida dos códigos, tendo em vista que essa informação se apresenta como uma consolidação interna de comunicação/execução explica (SINGH, 2011).

Figura 5 - Nuvem de palavras do tópico Whistle-blower

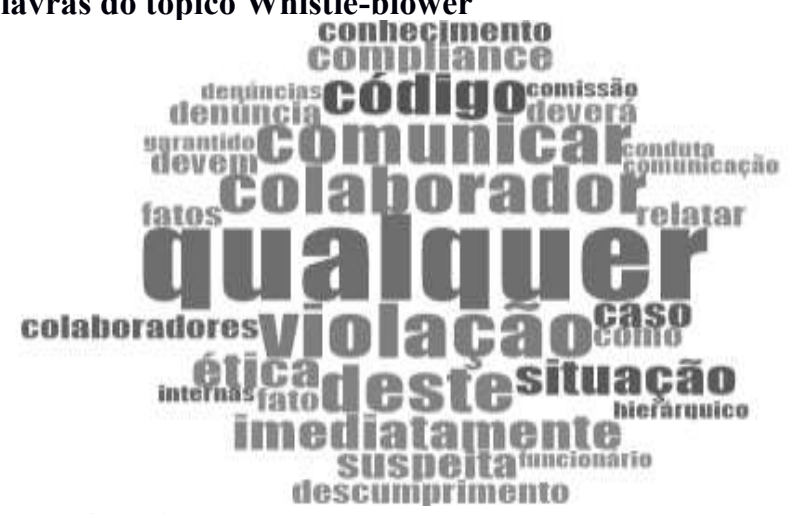

Fonte: Elaborada pelos autores (2016).

9) Prevenção e tratamento de fraudes

Assunto presente em todos os códigos de conduta analisados. O banco ABC declara que "Devemos nos abster de comportamento ilegal, fraudulento ou sem ética, principalmente com relação às negociações financeiras e/ou comerciais". Já o Banese trata em suas condutas inaceitáveis: "Autoria ou colaboração em operações que tenham como objetivo a conversão de ativos ilícitos em ativos lícitos (lavagem de dinheiro)". O banco Santander determina "Todos deverão cumprir de forma estrita as normas que são estabelecidas na Política de Prevenção à Lavagem de Dinheiro".

Todos os bancos em linha com a recomendação do IBGC que "A organização deve estabelecer uma política com conceitos e as diretrizes para a prevenção e o combate a atos ilícitos" (IBGC, 2009, p.70) de forma a ampliar a utilidade do código e, assim, impactar na efetividade percebido do código (SINGH, 2011). Além disso, destaca-se que a prática ilícita mais destacada nos códigos é a lavagem de dinheiro e corrupção, conforme destacado na Figura 6. 
Figura 6 - Nuvem de palavras do tópico prevenção e tratamento de fraudes

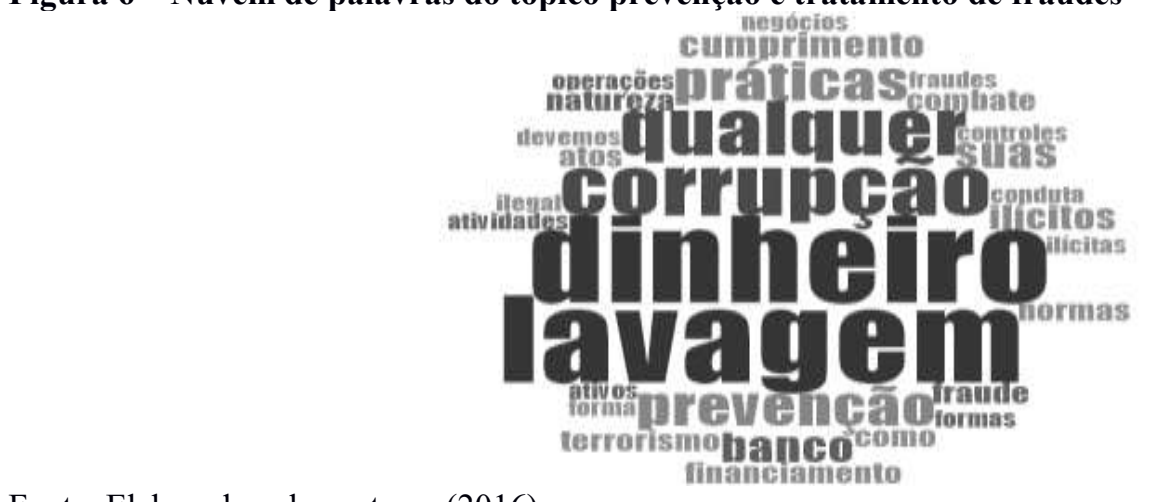

Fonte: Elaborada pelos autores (2016).

financiamento

10) Pagamentos ou recebimentos questionáveis

Tema abordado por pouco mais da metade das empresas, representando $60 \%$ do total da amostra. O banco Bradesco determina em seu princípio de integridade "é proibido aceitar, obter, conceder, pagar, prometer, patrocinar ou autorizar, direta ou indiretamente, qualquer benefício, pecuniário ou não, seja de que forma for, em favor próprio ou de quem quer que seja, que possam representar relacionamento impróprio".

O banco BTG Pactual dispõe que "Nunca aceitamos ou oferecemos suborno em troca de qualquer benefício ou vantagem". Todos os bancos possuem uma tratativa mandatória e proibitiva sobre esse tipo de conduta abordado nos códigos o que pode ser identificado também nas palavras mais frequentes sobre esse tópico.

Figura 7 - Nuvem de palavras do tópico pagamentos ou recebimentos questionáveis

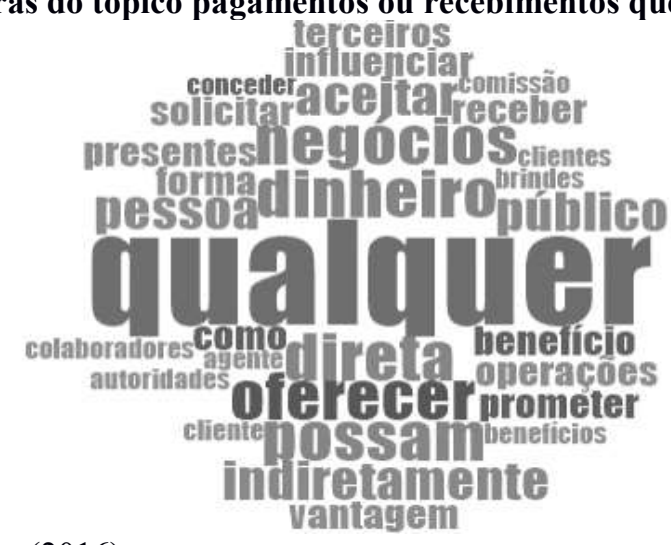

Fonte: Elaborada pelos autores (2016).

11) Recebimento de presentes e favorecimento

Matéria abordada por muitos bancos, compreendendo $75 \%$ do total da amostra analisada. Todos os bancos tratam como conduta proibitiva o recebimento de presentes e afins. O Itaú Unibanco orienta que "É inaceitável receber cortesias e contribuições de qualquer natureza ou valor, ainda que sejam apenas brindes, para não dar margem a suspeitas, sendo administrador ou colaborador da Diretoria de Compras do Itaú Unibanco".

Já o Sofisa dispõe que "O banco defende que se deve recusar o recebimento de presentes, vantagens pecuniárias ou materiais, de quem quer que seja, que possam representar relacionamento impróprio ou prejuízo de ordem financeira ou à sua reputação". Assim, os códigos estão alinhados com a recomendação geral de que a "empresa recuse o recebimento de 
presentes e outros favorecimentos passíveis de questionamento do ponto de vista moral" (AZEVEDO 2010, p.68). Essa premissa pode ser identificada na Figura 8 a seguir.

Figura 8 - Nuvem de palavras do tópico recebimento de presentes e favorecimento

Fonte: Elaborada pelos autores (2016).

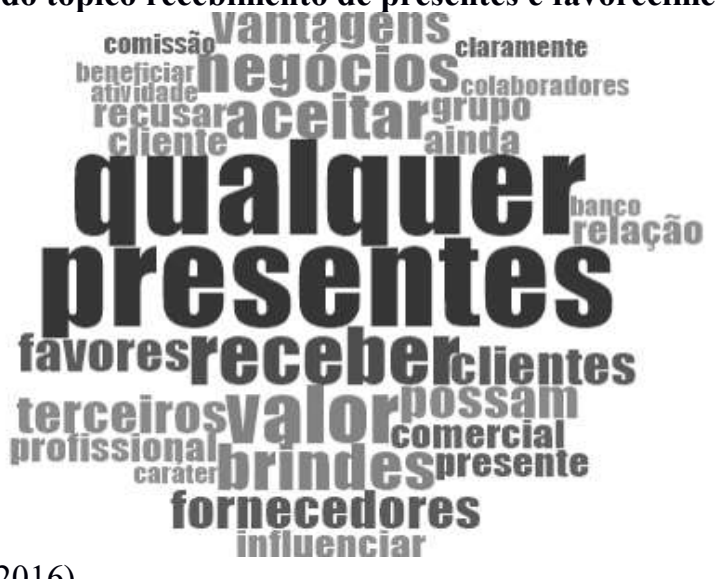

12) Doações

Assunto constante em apenas $20 \%$ dos códigos, o tema Doações foi regulado nos quatro bancos analisados. O banco Pine determina que "Doações em nome do banco devem ser obrigatoriamente avaliadas pela Alta Administração e pela área de Compliance, a qual obterá as aprovações necessárias conforme regras internas e legislação em vigor”.

O banco PAN trata que "Apenas a Diretoria pode autorizar doações para caridade em nome do banco. Colaboradores não podem levantar fundos e/ou pedir doações de colegas, clientes e fornecedores". O IBGC recomenda que "O Conselho de Administração deve ser o órgão responsável pela aprovação de todos os desembolsos relacionados às atividades políticas" (IBGC, 2009, p.69).

\section{3) Atividades Políticas}

Tópico abordado por pouco mais de metade da amostra dos códigos, representando $60 \%$ do total. O Banco do Brasil dispõe que "Não financiamos partidos políticos ou candidatos a cargos públicos, no Brasil e nos países em que atuamos. É dever do funcionário zelar para que no exercício de seus direitos políticos não haja envolvimento do nome da Empresa". Todos os bancos valorizam o caráter pessoal e individual das atividades políticas, quando permitidas.

O Bradesco trata que "A Organização não tem restrições quanto ao exercício, por parte dos funcionários, de seus direitos político-partidários, desde que em caráter estritamente pessoal e sem prejuízo para o banco". Nesse sentido, destaca-se que os códigos, ao tratarem desse assunto, traçam "diretrizes de como serão conduzidas as doações e contribuições, observada a legislação, e de como deve se portar o público interno em relação às atividades políticas no ambiente de trabalho" (AZEVEDO 2010, p.68) como é possível identificar na nuvem de palavras a seguir. 
Figura 9 - Nuvem de palavras do tópico atividades políticas

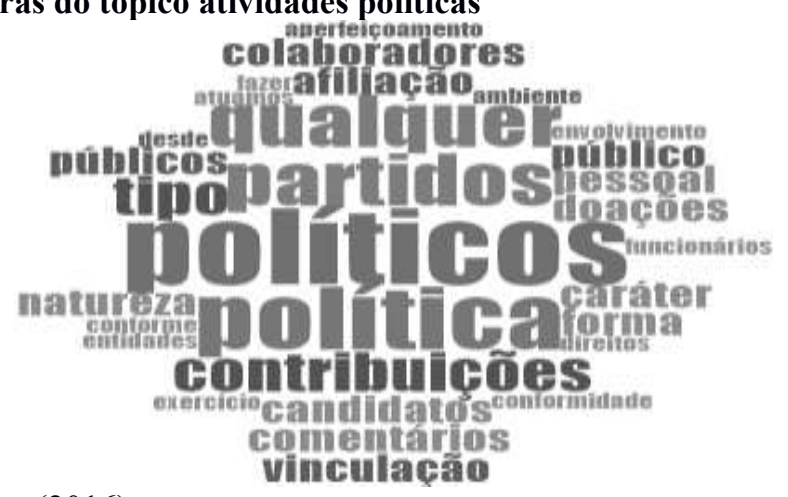

Fonte: Elaborada pelos autores (2016).

14) Direito à privacidade

Temática tratada por apenas 50\% dos códigos analisados. O Mercantil determina que sua "responsabilidade é assegurar que os direitos dos colaboradores sejam respeitados, buscando um relacionamento baseado na confiança, proporcionando um ambiente saudável [...] e preservando a privacidade e integridade das pessoas". Previsto na constituição, em seu artigo 50. "São invioláveis, a vida privada, a honra e a imagem das pessoas" (BRASIL, 1988).

Segundo o Banco do Brasil "Asseguramos a cada funcionário o acesso às informações pertinentes à sua privacidade, bem como o sigilo destas informações, ressalvados os casos previstos em lei”. Assim, verifica-se que mesmo sendo um tópico relevante, apenas a metade das organizações informa "objetivamente, qual é a política da empresa em relação ao tratamento de dados pessoais, as responsabilidades que assume perante as pessoas da organização" (AZEVEDO, 2010, p.68).

\section{5) Nepotismo}

Matéria abordada por $50 \%$ da amostra dos códigos analisados. O banco PAN dispõe que "Não recomendamos a contratação de parentes de Colaboradores, qualquer que seja o grau de parentesco, inclusive por afinidade. Por outro lado, recomendamos que a área de Recursos Humanos seja consultada sempre que houver necessidade de esclarecimentos".

Já o Santander orienta que "Os sujeitos ao Código não darão tratamento nem condições de trabalho especiais baseadas em relações pessoais ou familiares". O Conselho Nacional de Justiça determina que "Nepotismo é o favorecimento dos vínculos de parentesco nas relações de trabalho ou emprego. As práticas de nepotismo substituem a avaliação de mérito para o exercício da função pela valorização de laços de parentesco" (CONSELHO NACIONAL DE JUSTIÇA, 2015).

\section{6) Meio ambiente}

Tema abordado pela maioria dos bancos, compreendendo $80 \%$ da amostra de códigos. O Itaú Unibanco dispõe que "Avaliamos os impactos socioambientais de nossa atividade e adotamos práticas para a construção de valor compartilhado. É necessário realizar análises preventivas dos nossos riscos operacionais, financeiros, ambientais e de reputação, tendo em vista a perenidade do negócio".

Já o Sofisa trata em seus princípios "responsabilidade socioambiental, com a promoção e incentivo de ações para o desenvolvimento sustentável". Segundo a ISO 14001:2015 um sistema de gestão ambiental auxilia as organizações a identificar, monitorar, gerenciar e controlar suas questões de uma forma holística. Nesse sentido, nota-se que os códigos que

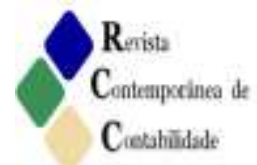


possuem esse item explicam "como a empresa deve agir em defesa do meio ambiente" (AZEVEDO, 2010, p.70). A Figura 9 apresenta a partir das palavras mais frequentes essas perspectivas.

Figura 10 - Nuvem de palavras do tópico meio ambiente

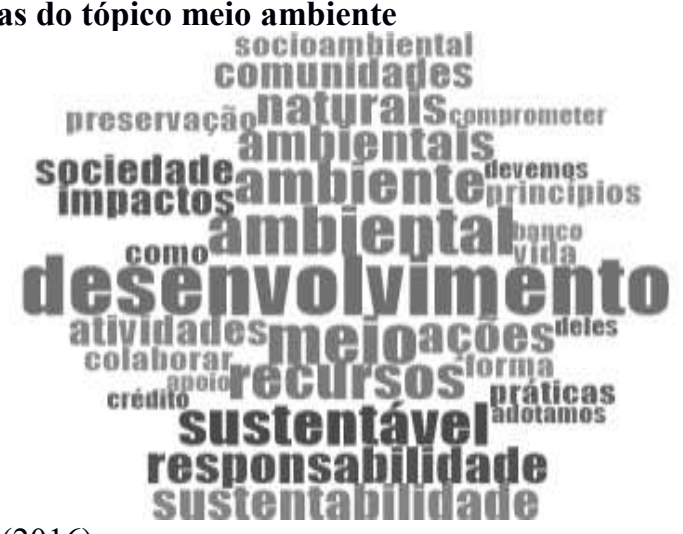

Fonte: Elaborada pelos autores (2016).

17) Discriminação no ambiente de trabalho

Todos os bancos tratam o assunto, que é regido em legislação, em seus códigos, demonstrando importância destinada ao mesmo. O Grupo Daycoval determina que "Não serão admitidos no banco, sob qualquer forma ou circunstância, qualquer tipo de discriminação de raça, religião, origem, nacionalidade, classe social, sexo, cor, idade ou deficiência física. Nenhum tipo de discriminação será tolerado".

Já o Banestes orienta que "É inaceitável qualquer atitude que discrimine as pessoas em função de cor, sexo, religião, origem, classe social, estado civil, idade, orientação sexual ou incapacidade física". Nesse sentido, destaca-se que essas declarações nos códigos vão ao encontro do que prediz o Art. $5^{\circ}$ da Constituição Federal de que "todos são iguais perante a lei, sem distinção de qualquer natureza [...]" (BRASIL, 1988). A Figura 11 a seguir destaca os diversos temas abordados nos códigos e que visão, em termos gerais, a não existência de preconceito algum.

Figura 11 - Nuvem de palavras do tópico discriminação no ambiente de trabalho

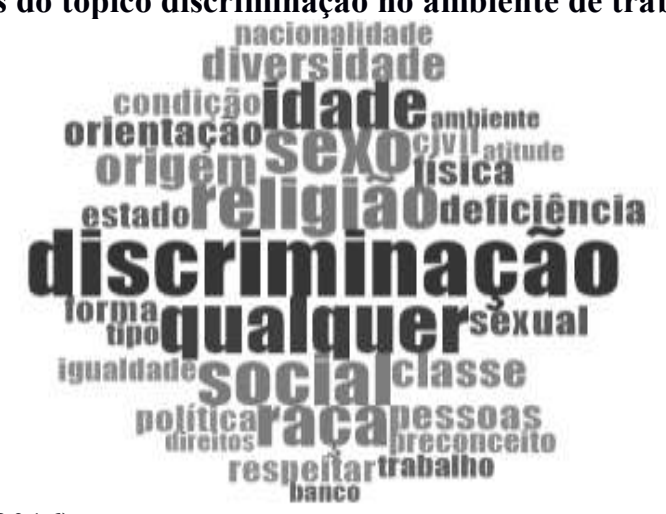

Fonte: Elaborada pelos autores (2016).

18) Assédio moral ou sexual

Tema presente em $90 \%$ dos códigos analisados neste estudo, sendo a prática de assédio, considerada um crime. O Banco do Nordeste determina que "compromete-se a: repudiar, coibir 
e punir qualquer procedimento que possa configurar assédio de qualquer natureza, seja de caráter físico, moral ou psicológico".

O Banco do Brasil dispõe que "Repudiamos condutas que possam caracterizar assédio de qualquer natureza". Nesse sentido, destaca-se que há a perspectiva da coibição e punição caso seja identificado algum comportamento nesse sentido. A seguir apresenta-se na Figura 12 com as palavras mais frequentes em relação ao tópico de assédio moral ou sexual, destacando que é considerado nesse tópico qualquer procedimento que possa configurar assédio.

Figura 12 - Nuvem de palavras do tópico assédio moral ou sexual

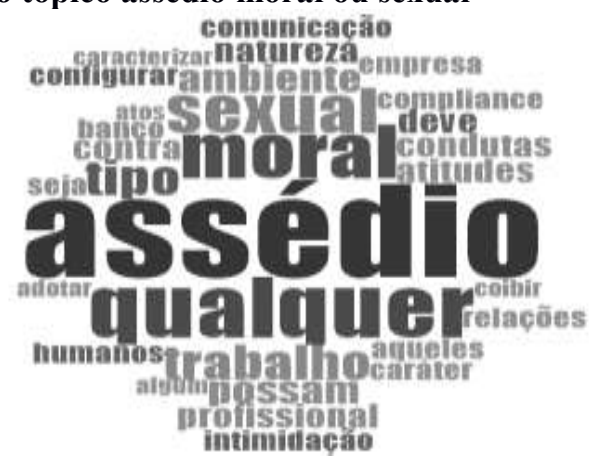

Fonte: Elaborada pelos autores (2016).

19) Segurança no trabalho

Tópico abordado por treze códigos, representando $65 \%$ do total da amostra estudada. O Sofisa trata que "O banco diligencia pela segurança e saúde no ambiente de trabalho, cumprindo de forma rigorosa o disposto pela Legislação Trabalhista, e busca assegurar aos colaboradores condições [...] de saúde que propiciem melhoria da qualidade de vida e do desempenho profissional.

Já o banco do Nordeste, determina que "está comprometido com a melhoria das condições de saúde, segurança e higiene, de modo a favorecer o equilíbrio harmônico no ambiente de trabalho". De acordo com a Consolidação das Leis do Trabalho (CLT) em seu artigo 154: "Cabe às empresas: I - cumprir e fazer cumprir as normas de segurança e medicina do trabalho[...]" (BRASIL, 1977). A Figura 13 destaca as palavras mais frequentes nesse tópico.

Figura 13 - Nuvem de palavras do tópico segurança no trabalho

Fonte: Elaborada pelos autores (2016).

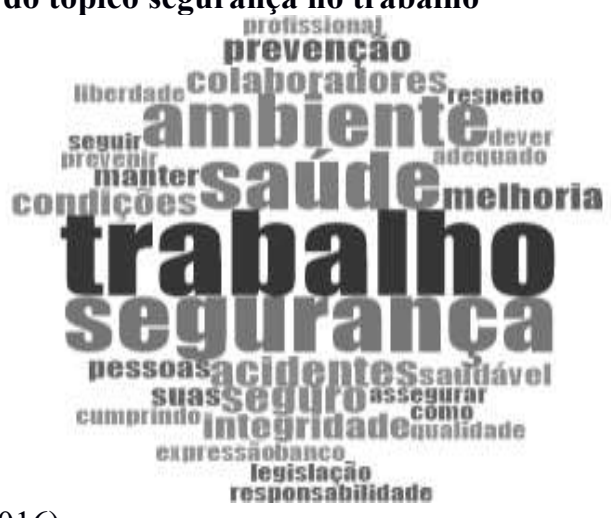

20) Exploração de trabalho adulto ou infantil

Matéria abordada por pouco menos da metade dos códigos, representando $45 \%$ do total da amostra. O banco Santander dispõe que "apoia, protege e preserva os Direitos Humanos, 
adotando políticas e práticas que contribuam para a erradicação do trabalho infantil, do trabalho escravo, forçado ou compulsório e da exploração sexual de crianças e adolescentes".

Já o Banco do Brasil aborda que "Afirmamos nosso compromisso com a erradicação de todas as formas de trabalho degradante: infantil, forçado e escravo". Segundo a CLT nos artigos 402 e seguintes. Art. 402: "Considera-se menor para os efeitos desta Consolidação o trabalhador de quatorze até dezoito anos". Art. 403: "É proibido qualquer trabalho a menores de dezesseis anos de idade, salvo na condição de aprendiz, a partir dos quatorze anos" (BRASIL, 1943).

\section{1) Relações com a comunidade}

Tópico abordado por $75 \%$ dos códigos analisados, porém amplamente discorrido pelos mesmos. O Bradesco dispõe que "Devemos ter o firme compromisso de praticar, incentivar e valorizar a preservação ambiental, buscando convergir os objetivos empresariais para os anseios e interesses da comunidade em que atuamos, sempre em linha com o desenvolvimento sustentável".

Já o Pine determina que "através de seus profissionais, deve buscar agregar constantemente ao desenvolvimento social do país. Também são realizadas aplicações em projetos sociais e culturais que possam ser traduzidos em benefícios à comunidade". O tema comunidade presente no código, além de representar um orientador para ações, tanto pessoais como institucionais, evidencia ao mercado e à comunidade o valor e importância que a mesma representa frente à organização (AZEVEDO, 2010). A Figura 14 destaca as palavras mais frequentes deste tópico.

Figura 14 - Nuvem de palavras do tópico relações com a comunidade

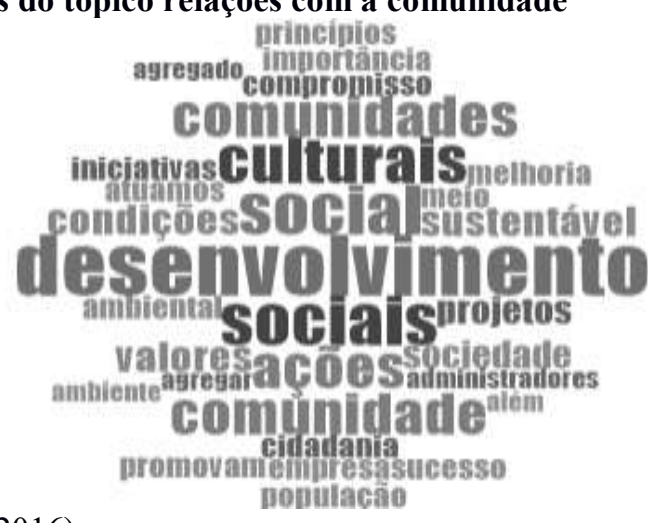

Fonte: Elaborada pelos autores (2016).

\section{2) Uso de álcool e drogas}

Temática tratada em menos da metade dos códigos, representando $35 \%$ do total dos bancos analisados. O banco BRB trata em seu código que "Não será aceito, no ambiente profissional, o consumo de substâncias que alterem o humor, a capacidade cognitiva e laborativa do empregado, administrador ou colaborador, ou consumo de quaisquer outras substâncias não permitidas por lei”.

O banco Indusval trata em seu capítulo de proibições "Utilizar, vender, distribuir ou ter posse de bebidas alcoólicas ou qualquer produto ou substância ilícita como drogas e armas". Todos os bancos tratam tal prática como conduta proibitiva. Segundo a CLT, em seu artigo 482, configura justa causa para rompimento do contrato de trabalho, dentre outros motivos, a embriaguez habitual ou em serviço (BRASIL, 1943). 


\section{Considerações Finais}

Esta pesquisa buscou verificar a estrutura e conteúdo dos temas dos códigos de conduta das empresas do setor de atuação financeiro listadas na BM\&FBovespa à luz das recomendações feitas pelo Instituto Brasileiro Governança Corporativa (IBGC). Para isso, foram analisadas as informações dos códigos de conduta disponíveis nos websites de vinte instituições financeiras do setor de atuação financeiro da BM\&FBovespa pertencentes à amostra, a partir recomendações do IBGC.

Em relação à aderência dos códigos, observou-se um índice médio geral de adesão de $62 \%$, número pouco expressivo, mas relevante quando comparado ao resultado da mesma pesquisa realizada por Azevedo (2010), na qual esse índice era de 40\%. Também é possível verificar que todos os bancos revisaram e atualizaram seus códigos de conduta no espaço de tempo que compreende as duas pesquisas, tendo sido o aumento médio de cinco assuntos por código. Além disso, quatro bancos que em 2010 não divulgavam seus respectivos códigos de conduta, em 2016 apresentam em seus websites os mesmos disponíveis, demonstrando maior transparência e comprometimento em relação ao tema ética.

Com base na análise de estrutura dos códigos, pode-se verificar que pouco mais da metade dos bancos presentes nessa amostra segue uma forma similar de estruturação de seus códigos. Tópicos como Valores e Princípios da organização estão delineados em mais de $80 \%$ dos mesmos. Também se percebe que, em média, metade dos bancos contemplam os principais grupos de relações internas e externas, seus stakeholders, como acionistas, clientes, fornecedores, poder público, entidades de classe, etc. Além disso, temas como Conduta Esperada pela organização, assim como Condutas Inaceitáveis, também são contemplados, demonstrando a expectativa da empresa em relação ao comportamento de seus membros.

A partir da essência dos códigos e análise realizada nos mesmos, é possível perceber que cada banco aborda e trata de forma particular cada assunto presente em seu código. Seja como conduta mandatória, ou como expectativa de postura de seus membros frente a certas situações. Mas todos alicerçam em seus princípios e valores qual deve ser a conduta que rege as relações de trabalho. Além disso, de forma mais rasa ou aprofundada, todos os assuntos, com exceção de arbitragem, são abordados pelos bancos dessa amostra.

Pode-se inferir, de modo geral, que o compromisso com a ética e transparência por parte das organizações vem crescendo ao longo dos anos, ainda que aquém de um nível satisfatório. Assim, destaca-se que este estudo contribui, tendo focado nas instituições financeiras, setor regulado que impacta economicamente o país, para a literatura de Governança Corporativa de forma a demonstrar o crescimento de uma consciência ética a partir do aumento da adoção aos códigos de conduta. Além disso, destaca-se que a presença dos códigos formaliza diversos aspectos comportamentais de forma a mediar as relações entre os stakeholders e até limitar a ação dos gestores. Portanto, tendo em vista os temas abordados nesse código é possível destacar a relevância desse mecanismo como um mediador dos conflitos de interesses existentes nas organizações conforme prediz a Teoria da Agência.

Como limitação, destaca-se que o presente estudo está focado somente em instituições financeiras. Assim, estudos futuros poderiam abordar outros tipos de setores. Além disso, sugere-se que outros estudos enfoquem o papel da regulação em um setor econômico para a adoção de códigos de conduta. Outra possibilidade de estudo futuro, tendo em vista que este estudo se limitou a analisar a estrutura e conteúdo dos temas dos códigos de conduta, propõese que estudos futuros investiguem a forma de apresentação desses códigos aos membros das organizações, seja em treinamento, apresentação no momento de contratação, ou uma simples 
distribuição, além de saber se os mesmos são conhecidos por todos. E ainda, outro tema a ser proposto é a forma como as entidades tratam os dilemas e conflitos éticos e quais canais são disponibilizados para denúncias.

\section{Referências}

ANDRADE, A.; ROSSETTI, J. P. Governança corporativa: fundamentos, desenvolvimento e tendências. 4. ed., São Paulo, Atlas, 2009.

ARRUDA, Maria Cecília Coutinho; WHITAKER, Maria do Carmo; RAMOS, José Maria Rodriguez. Fundamentos de Ética Empresarial e Econômica. 4. ed., São Paulo, Atlas, 2009.

AZEVEDO, H. Código de Conduta: grau de adesão às recomendações do IBGC pelas empresas listadas na BM\&FBovespa. 2010. 132 f. Dissertação (Mestrado Profissional em Administração e Controladoria) - Curso de Pós-Graduação em Administração e Controladoria da Universidade Federal do Ceará, Fortaleza, 2010.

BM\&FBOVESPA. Relações com Investidores. Governança Corporativa. Estatutos, Códigos e Políticas. Política de Divulgação de Informações e Negociação de Valores Mobiliários. Manual das Políticas de Divulgação e Negociação de Valores Mobiliários. 2015. Disponível em: $<$ http://ri.bmfbovespa.com.br/fck_temp/26_72/file/Manual\%20das\%20Pol\%C3\%ADticas\%20de $\% 20$ Divulga $\% \mathrm{C} 3 \% \mathrm{~A} 7 \% \mathrm{C} 3 \% \mathrm{~A} 3 \mathrm{o} \% 20 \mathrm{e} \% 20 \mathrm{de} \% 20$ Negocia $\% \mathrm{C} 3 \% \mathrm{~A} 7 \% \mathrm{C} 3 \% \mathrm{~A} 3 \mathrm{o} \_2015$ 02_26.p df > . Acesso em: 20/10/2017

BRASIL Constituição (1988). Disponível em:

$<$ http://www.planalto.gov.br/ccivil_03/Constituicao/Constituicao.htm>. Acesso em 10 out. 2017.

BRASIL Lei 5.452 de 1 de Maio de 1943. Dispõe sobre a Consolidação das Leis de Trabalho. Disponível em < http://www.planalto.gov.br/ccivil_03/decreto-lei/Del5452.htm>. Acesso em 02 out. 2017.

BRASIL Lei 6.514 de 22 de Dezembro de 1977. Dispõe sobre alterações no Capítulo V do Título II da Consolidação das Leis do Trabalho, relativo a segurança e medicina do trabalho e dá outras providências. Disponível em $<$ http://www.planalto.gov.br/ccivil_03/leis/16514.htm $>$. Acesso em 02 out. 2017.

BRASIL. Lei 12.846 de 1 de Agosto de 2013. Dispõe sobre a responsabilização administrativa e civil de pessoas jurídicas pela prática de atos contra a administração pública, nacional ou estrangeira, e dá outras providências. Disponível em:

$<$ http://www.planalto.gov.br/ccivil_03/_ato2011-2014/2013/lei/112846.htm>. Acesso em: 10 set. 2017.

BRIDOUX, F.; STOELHORST, J. W. Microfoundations for stakeholder theory: Managing stakeholders with heterogeneous motives. Strategic Management Journal, v. 35, n. 1, p. $107-$ 125, 2014. https://doi.org/10.1002/smj.2089

CONSELHO NACIONAL DE JUSTIÇA-CNJ. Nepotismo. Disponível em: $<$ http://www.cnj.jus.br/356-geral/13253-o-que-e-nepotismo>. Acesso em: 12 out. 2017. 
DAVIDSON, B. I.; STEVENS, D. E. Can a code of ethics improve manager behavior and investor confidence? An experimental study. The Accounting Review, v. 88, n. 1, p. 51-74, 2013. https://doi.org/10.2308/accr-50272

EISENHARDT, K. M. Agency theory: An assessment and review. Academy of Management, v. 14, n. 1, p. 57-74, 1989. https://doi.org/10.2307/258191

ERWIN, P. M. Corporate codes of conduct: the effects of code content and quality on ethical performance. Journal of Business Ethics, v. 99, n. 4, p. 535-548, 2011.

https://doi.org/10.1007/s10551-010-0667-y

FREEMAN, R. E.; HARRISON, J. S.; WICKS, A. C. Managing for Stakeholders: Survival, Reputation, and Success. New Haven: Yale University Press. 2007.

GIL, A. C. Métodos e Técnicas de Pesquisa Social. 6 ed. São Paulo: Atlas, 2008.

INSTITUTO BRASILEIRO DE ÉTICA NOS NEGÓCIOS. Pesquisa código de ética corporativo 2014. Disponível em: < http://www.pesquisacodigodeetica.org.br>. Acesso em 15 out. 2017.

INSTITUTO BRASILEIRO DE GOVERNANÇA CORPORATIVA (IBGC). Código das melhores práticas de governança corporativa. 4. ed., São Paulo: IBGC, 2009.

ISO-International Organization for Standardization. Management standards ISO 1401:2015. Disponível em: <https://www.iso.org/obp/ui/\#iso:std:iso:14001:ed-3:v1:en>. Acesso em 02 out. 2017.

LANGLOIS, C. C.; SCHLEGELMILCH, B. B. Do corporate codes of ethics reflect national character? Evidence from Europe and the United States. Journal of International Business Studies, v. 21, n. 4, p. 519-539, 1990.

MANUAL EMPREGADOR URBANO. Assédio Moral e Sexual Disponível em: $<$ http://acesso.mte.gov.br/data/files/FF8080812CD2239D012CE0B8674478C6/manual_emprega dor_port.pdf $>$. Acesso em 02 out. 2017.

OLIVEIRA, A. B. S. Métodos da Pesquisa Contábil. São Paulo: Atlas, 2011.

RAUPP, F. M.; BEUREN, I. M. Metodologia da Pesquisa Aplicável às Ciências Sociais. In: BEUREN, Ilse Maria (Org.) Como Elaborar Trabalhos Monográficos em Contabilidade: Teoria e Prática. 3 ed. São Paulo: Atlas, 2013, p. 76-97.

SARTURI, G. Distribuição de valor para o stakeholder funcionário e desempenho organizacional. 2016. Tese (Doutorado em Administração) - Faculdade de Economia, Administração e Contabilidade, Universidade de São Paulo, São Paulo.

SCHWARTZ, M. The nature of the relationship between corporate codes of ethics and behaviour. Journal of Business Ethics, v. 32, n. 3, p. 247-262, 2001.

https://doi.org/10.1023/A:1010787607771 
SILVA, V.G.; GOMES, J.S. O uso do código de conduta ética como instrumento de controle gerencial: estudo de casos em empresas internacionalizadas. Revista Contemporânea em Contabilidade, v. 10, p. 111-127, 2008. http://dx.doi.org/10.5007/2175-8069.2008v5n10p111

SIMONS, R. How new top managers use control systems as levers of strategic renewal. Strategic Management Journal, v. 15, n. 3, p. 169-189, 1994. https://doi.org/10.1002/smj.4250150301

SINGH, J. B. Determinants of the effectiveness of corporate codes of ethics: an empirical study. Journal of Business Ethics, v. 101, n. 3, p. 385-395, 2011. https://doi.org/10.1007/s10551-0100727-3

SROUR, R. H. 2014. Ética empresarial. 4. ed., São Paulo, Atlas, p. 29

STEVENS, B. Corporate Ethical Codes: effective instruments for influencing behavior. Journal of Business Ethics, v. 78, n.4, p. 601-609, 2008. http://dx.doi.org/10.1007/s10551-007-9370-z

TEIXEIRA, E. B. A Análise de Dados na Pesquisa Científica: Importância e Desafios em Estudos Organizacionais. Revista Desenvolvimento em Questão, Ijuí, v. 1, n. 2, p. 177-201, 2003.

WHITAKER, M. C.; RAMOS, J. M. R. Ética e as linhas mestras do Código das Melhores Práticas de Governança Corporativa do IBGC - Instituto Brasileiro de Governança Corporativa. Disponível em: $<\mathrm{http} / /$ www.eticaempresarial.com.br/site/pg.asp?pagina $=$ detalhe artigo\&codigo $=401 \&$ tit pagina $=$ MONOGRAFIAS\&nomeart $=$ s\&nomecat $=\mathrm{n}>$. Acesso em: $23 / 10 / 2017$ 